\title{
A taxonomic account of non-geniculate coralline algae (Corallinophycidae, Rhodophyta) from shallow reefs of the Abrolhos Bank, Brazil
}

\author{
Michel B. Jesionek ${ }^{1}$, Ricardo G. Bahia ${ }^{1}$, Jazmín J. Hernández-Kantún ${ }^{2}$, Walter H. Adey ${ }^{2}$, \\ Yocie Yoneshigue-Valentin ${ }^{3}$, Leila L. Longo ${ }^{4}$ and Gilberto M. Amado-Filho, ${ }^{1, *}$ \\ ${ }^{1}$ Instituto de Pesquisas Jardim Botânico do Rio de Janeiro, Diretoria de Pesquisa Científica, Rua Pacheco Leão 915, Rio de \\ Janeiro, RJ 22460-030, Brazil \\ ${ }^{2}$ Department of Botany, National Museum of Natural History, Smithsonian Institution, Washington, D.C. 20560, USA \\ ${ }^{3}$ Departamento de Botânica, Instituto de Biologia, Universidade Federal do Rio de Janeiro (UFRJ), Av. Carlos Chagas Filho \\ 373, Rio de Janeiro, RJ 21941-902, Brazil \\ ${ }^{4}$ Departamento de Oceanografia e Ecologia, Universidade Federal do Espírito Santo, Vitória, ES 29075-910, Brazil
}

The Abrolhos Continental Shelf (ACS) encompasses the largest and richest coral reefs in the southern Atlantic Ocean. A taxonomic study of non-geniculate coralline algae (NGCA) from the region was undertaken using both morpho-anatomical and molecular data. Specimens of NGCA were collected in 2012 and 2014 from shallow reefs of the ACS. Phylogenetic analysis was performed using dataset of $p s b$ A DNA sequences from 16 specimens collected in the ACS and additional GenBank sequences of related NGCA species. Nine common tropical reef-building NGCA species were identified and described: Hydrolithon boergesenii, Lithophyllum kaiseri, Lithophyllum sp., Lithothamnion crispatum, Melyvonnea erubescens, Pneophyllum conicum, Porolithon onkodes, Sporolithon ptychoides, and Titanoderma prototypum. A key for species identification is also provided in this study. Our molecular phylogenetic analyses suggest that Lithophyllum sp. corresponds to a new species. Our study also confirms that Lithophyllum kaiseri is a new record in Brazil. The psbA sequences of Lithophyllum kaiseri and Melyvonnea erubescens matched with type specimens indirectly. The taxonomic identification of the remaining species was supported by morpho-anatomical evidences as DNA sequences of their types or topotypes remain unavailable.

Key Words: Atlantic; Corallinales; Hapalidiales; psbA; Sporolithales; taxonomy

\section{INTRODUCTION}

The Abrolhos Continental Shelf (ACS), also known as the Abrolhos Bank, encompasses an area of approximately $46,000 \mathrm{~km}^{2}$. It is home to the largest coralline algal formations in the southern Atlantic Ocean (Amado-Filho et al. 2012, Moura et al. 2013). The area represents the most biodiverse marine ecosystem in the South Atlantic (Dutra et al. 2005). It is a global marine conservation priority (Moura 2000). Nearly 300 species of fish and 20 species of reef-building corals are recorded in a benthic mosaic of rhodolith beds, hard calcareous reefs, soft bot-
(7) \$ This is an Open Access article distributed under the terms of the Creative Commons Attribution Non-Commercial License (http://creativecommons.org/licenses/by-nc/3.0/) which permits unrestricted non-commercial use, distribution, and reproduction in any medium, provided the original work is properly cited.
Received March 14, 2016, Accepted November 16, 2016

* Corresponding Author

E-mail: gilbertoamadofilho@gmail.com

Tel: +55-21-32042150, Fax: +55-21-23042071 


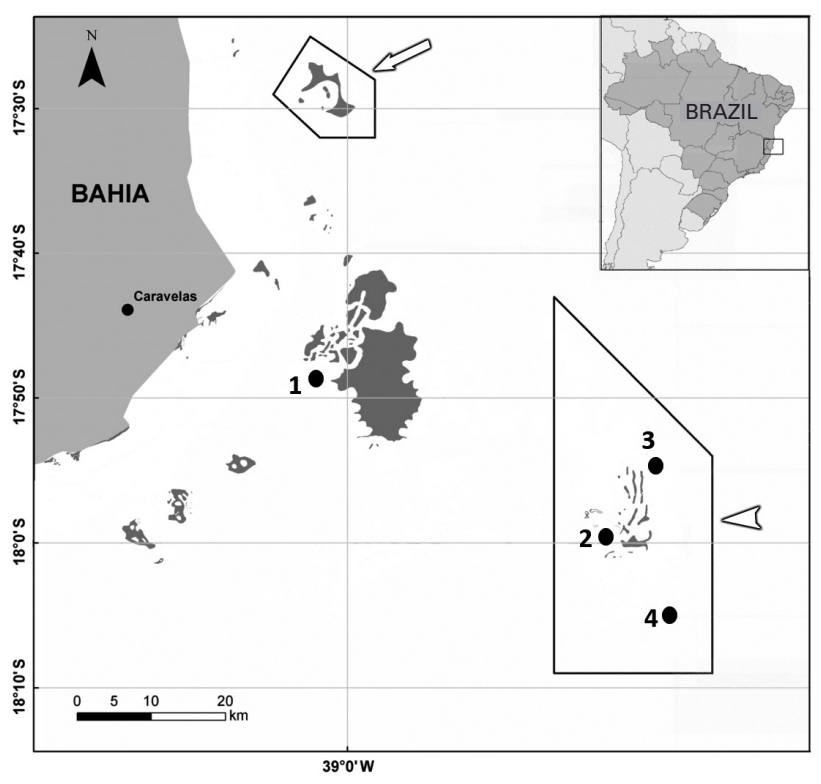

Fig. 1. Study sites along the Abrolhos Continental Shelf. 1, Pedra de Leste (inner reef arc, unprotected); 2, Abrolhos Archipelago (outer reef arc, marine protected area); 3, Reefs from Parcel dos Abrolhos (outer reef arc, marine protected area); 4 , Recife Califórnia (outer reef arc, marine protected area). Note the delimitation of the Abrolhos Marine National Park comprising the Timbebas reef closer to coast (arrow, not investigated here) and the more oceanic reef sites 2-4.

tom environments, mangroves, and vegetated sandbanks (Amado-Filho et al. 2012, Moura et al. 2013). The ACS is especially important because of it has high production of $\mathrm{CaCO}_{3}$ from the world's largest rhodolith beds with a total production of $0.025 \mathrm{Gt}^{-1}$ (Amado-Filho et al. 2012). In addition, it has a high diversity of associated organisms (Brasileiro et al. 2016). The Abrolhos Marine National Park (AMNP, approximately $880 \mathrm{~km}^{2}, 1.7 \%$ of the ACS), a no-take marine protected area, was established in 1983. It comprises two discrete portions of the shelf: 1) the Timbebas reefs and 2) the Abrolhos Archipelago and the Parcel dos Abrolhos (Fig. 1).

Non-geniculate coralline red algae (NGCA) (Corallinales, Hapalidiales and Sporolithales, Rhodophyta) rank as the fifth most abundant benthic organisms in the ACS. Along with corals, NGCA are considered as the main builders of ACS reefs (Francini-Filho et al. 2013). The NGCA provide habitats for diverse flora and fauna (Nelson 2009). Some species are known to be cues for the settlement and metamorphosis of the larval stages of key invertebrate taxa such as corals and economically important mollusks (Roberts 2001, Harrington et al. 2004). NGCA have complex taxonomic history. This is mainly due to their phenotypic plasticity which can be influenced by environmental conditions and the high number of cryptic species. In addition, their identification is difficult due to their calcified thalli that require time consuming and challenging procedures to observe the essential anatomical characters (Riosmena-Rodríguez et al. 1999, Saunders 2005, Maneveldt and Keats 2008, Bittner et al. 2011, Sissini et al. 2014, Nelson et al. 2015). Identification of NGCA exclusively based on morpho-anatomy faces some limitations, including the need to examine fertile specimens of a particular life cycle stage for their identification at species level (Harvey et al. 2005).

Several recent studies have used molecular data to study coralline algae in order to reassess the classification of NGCA group at different levels, including species (Walker et al. 2009, Kato et al. 2013, Sissini et al. 2014, Bahia et al. 2015), genus (Bailey 1999, Bittner et al. 2011), subfamily (Kato et al. 2011, Rösler et al. 2016), and order levels (Le Gall et al. 2010, Nelson et al. 2015). These studies reinforce the importance of combining morpho-anatomical data with molecular data for their identification. Increasingly DNA barcoding of NGCA is used to provide more reliable taxonomic characters and the understanding of their biogeography (Kato et al. 2013, Carro et al. 2014, Hernandez-Kantun et al. 2016).

Taxonomic studies of coralline algae in the southwestern Atlantic have mostly been devoted to unattached, free-living, and rhodolith-forming species (e.g., VillasBoas et al. 2009, Amado-Filho et al. 2010, 2012, Bahia et al. 2011, 2014, 2015, Bahia 2014). Consequently, little is known about the attached NGCA species compositions, their taxonomy, or distribution in the southwestern Atlantic (Mariath et al. 2012, Bahia et al. 2014, Crespo et al. 2014, Tâmega et al. 2014). To the best of our knowledge, only two previous studies (Figueiredo and Steneck 2000, Tâmega et al. 2014) have studied NGCA of the ACS reefs. Figueiredo and Steneck (2000) have listed 11 NGCA species. However, they did not provide any description. More importantly, their specimens could not be traced in RB (Jardim Botânico do Rio de Janeiro, Rio de Janeiro, Brazil), making positive identifications of their specimens impossible. Tâmega et al. (2014) have described four species as the main NGCA reef-forming species in the ACS, namely Lithophyllum stictaeforme (Areschoug) Hauck, Porolithon onkodes, Spongites fruticulosus Kützing, and Neogoniolithon atlanticum Tâmega, Riosmena-Rodríguez, Mariath \& M. Figueiredo. However, these taxa were not analyzed molecularly.

Therefore, the aim of this study was to use both morpho-anatomical data and molecular data to improve the current knowledge of NGCA, one of the main reef-building groups of the ACS. 


\section{MATERIALS AND METHODS}

\section{Sampling and study sites}

Specimens were collected from ACS by SCUBA diving in shallow reefs (2-7 m). NGCA were taken from Pedra de Leste (1), Abrolhos Archipelago (2), Parcel dos Abrolhos (3), and Recife Califórnia (4) (Fig. 1). Of the four sites, only Pedra de Leste is located at the inner reef arc falling outside of the AMNP marine protected area. The remaining sites are within the AMNP. They are located at the outer reef arc.

Fragments measuring around $10 \mathrm{~cm}^{2}$ were collected from substrates using a hammer and chisel. Samples were brushed to remove epibionts, air dried, and preserved in silica gel, including those selected for morphoanatomical analysis.

\section{Morpho-anatomical analysis}

Samples used for light microscopy examination were prepared using histological method described by Maneveldt and van der Merwe (2012). No specific method was used for re-hydration prior to decalcification. Satisfactory results were obtained by putting dry samples directly in $10 \%$ nitric acid for decalcification following the steps for embedding and sectioning described by Maneveldt and van der Merwe (2012). Using this alternative method, exposure to formaldehyde solution (normally used for algae fixation) was avoided. For species description, growth-form terminology followed Woelkerling et al. (1993) and thallus anatomical terminology followed Adey and Adey (1973). The distance between primary pit connections was determined for cell length measurements. The maximum cell lumen at right angle to the length was measured for cell diameter. Conceptacle measurements followed Adey and Adey (1973).

\section{Molecular analysis}

Genomic DNA extraction and polymerase chain reaction (PCR) amplification were carried out at the Molecular Biology Laboratory of the Smithsonian National Museum of Natural History, Washington DC, USA. DNA extraction was performed using fragments of thalli $(\sim 15$ $\mathrm{mg}$ ) that were visually clean and free of epibionts. For DNA extraction, Qiagen DNeasy Blood and Tissue Kit (Qiagen, Crawley, UK) was used following the protocol of Broom et al. (2008) with slight modification. The $p s b \mathrm{~A}$ gene was amplified using primers $p s b A-\mathrm{F} 1$ and $p s b A-\mathrm{R} 2$ using published protocol of Yoon et al. (2002).

The PCR mix contained $2.5 \mu \mathrm{L}$ of $10 \times$ buffer, $2 \mu \mathrm{L}$ dNTPs (10 mM), $1.5 \mu \mathrm{L} \mathrm{MgCl}_{2}(25 \mathrm{mM}), 0.5 \mu \mathrm{L}$ bovine serum albumin), $1 \mu \mathrm{L}$ of each primer (forward and reverse) (10 $\mu \mathrm{M}), 0.2 \mu \mathrm{L}$ Invitrogen Taq polymerase $\left(5 \mu \mathrm{g} \mu \mathrm{L}^{-1}\right), 15.8 \mu \mathrm{L}$ HyPure TM Cell Culture Grade Water (Thermo Scientific, Milwaukee, WI, USA), and $1 \mu \mathrm{L}$ DNA template. The PCR cycle consisted of the following: an initial denaturation step at $94^{\circ} \mathrm{C}$ for $5 \mathrm{~min} ; 35$ cycles of denaturation at $94^{\circ} \mathrm{C}$ for $30 \mathrm{~s}$, annealing at $52^{\circ} \mathrm{C}$ for $45 \mathrm{~min}$, and elongation at $72^{\circ} \mathrm{C}$ for $1 \mathrm{~min}$; one final cycle at $94^{\circ} \mathrm{C}$ for $30 \mathrm{~s}$ and a final extension at $72^{\circ} \mathrm{C}$ for $7 \mathrm{~min}$. PCR products were visualized and quantified on agarose gels and sequenced commercially at Macrogen Inc. (Seoul, Korea).

\section{Phylogenetic construction}

The dataset comprised of $16 p s b$ A sequences generated in the present study and 46 sequences selected from GenBank (Supplementary Table S1) using the Basic Local Alignment Search Tool (BLAST). Two GenBank sequences from specimens in the order of Rhodogorgonales (Corallinophycidae, Rhodophyta) were used as outgroup (Supplementary Table S1).

Phylogenetic relationships were analyzed using maximum likelihood (ML) and neighbor joining (NJ) analysis with bootstrap (BS) of 1,000 replicates for each data set (Felsenstein 1985). It was performed with Geneious R7 and MEGA6 (Tamura et al. 2013). The jModelTest 2.1.4 (Darriba et al. 2012) was used to estimate model parameters.

\section{RESULTS AND DISCUSSION}

Nine non-geniculate coralline red algal species were identified from shallow reefs of the ACS based on morpho-anatomical and DNA data. They comprised of representatives of the Corallinales [Hydrolithon boergesenii (Foslie) Foslie, Lithophyllum kaiseri (Heydrich) Heydrich, Lithophyllum sp., Pneophyllum conicum (E. Y. Dawson) Keats, Y. M. Chamberlain \& M. Baba, Porolithon onkodes (Heydrich) Foslie, and Titanoderma prototypum (Foslie) Woelkerling, Y. M. Chamaberlain \& P. C. Silva], Hapalidiales [Melyvonnea erubescens (Foslie) Athanasiadis \& D. L. Ballantine and Lithothamnion crispatum Hauck], and Sporolithales (Sporolithon ptychoides Heydrich). The distributions of these species are shown in Table 1. Abrolhos Archipelago was the richest site. All identified NGCA species were found at this site. 
A key to species, detailed species descriptions, and comparisons with related species, including molecular data, are shown below:

\section{Key to common non-geniculate coralline red algae in shallow reefs of the ACS}

1. Tetra/bisporangia cruciately divided, borne in calcified compartments grouped into sori

Sporolithon ptychoides

Tetra/bisporangia zonately divided, borne in roofed conceptacles

2. Tetra/bisporangia producing apical plugs and borne in multiporate conceptacles $-3$ Tetra/bisporangia not producing apical plugs and borne in uniporate conceptacles ------------------- 4

3. Epithallial cells with distal walls flattened and flared. Roofs of mature conceptacles pitted with depressions resulting from disintegration of rosette cells surrounding the pores Lithothamnion crispatum Epithallial cells with distal walls rounded or flattened but not flared. Roofs of mature conceptacles not pitted with depressions --------- Melyvonnea erubescens

4. Adjacent filaments joined primarily by secondary pit

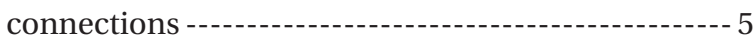
Adjacent filaments joined primarily by cell fusions -- 6

5. Thallus fruticose, not applanate --- Lithophyllum kaiseri or Lithophyllum sp.* Thallus layered and applanate, giving the thallus a terraced appearance in surface view

- Titanoderma prototypum
6. Thallus dimerous, trichocytes arranged singly or in pairs ------- Hydrolithon boergesenii Thallus monomerous, trichocytes arranged in large, tightly packed horizontal fields ----------------- 7

7. Tetrasporangial pore canals lined by a ring of conspicuous and enlarged cells that are orientated more-orless perpendicularly (vertically orientated) to the roof surface ------------ Porolithon onkodes Tetrasporangial pore canals lined by cells oriented more-or-less parallel or at a sharp angle to the conceptacle roof surface ---------- Pneophyllum conicum *No remarkable morpho-anatomical differentiation was observed for Lithophyllum kaiseri and Lithophyllum sp.

\section{Species descriptions}

\section{Corallinales P. C. Silva \& H. W. Johansen \\ Corallinaceae J.V. Lamouroux \\ Hydrolithoideae A. Kato \& M. Baba in A. Kato et al. \\ Hydrolithon (Foslie) Foslie \\ Hydrolithon boergesenii (Foslie) Foslie}

Habit and ecological observations. Thalli attached, encrusting to lumpy (Fig. 2A). Thallus surface generally smooth. Color of living thalli whitish or pink to purple. Species limited to shallow areas (2-5 $\mathrm{m}$ depth) of the reef with direct exposure to sunlight. External appearance and ecological niche similar to that of Porolithon onkodes, making field identification difficult.

Table 1. Non-geniculate coralline algae species distribution along the shallow reefs of the Abrolhos Continental Shelf

\begin{tabular}{|c|c|c|c|c|}
\hline \multirow{2}{*}{ Species } & \multirow{2}{*}{$\begin{array}{l}\text { Inner reef arc } \\
\text { Pedra de Leste }\end{array}$} & \multicolumn{3}{|c|}{ Outer reef arc } \\
\hline & & $\begin{array}{c}\text { Abrolhos } \\
\text { Archipelago }\end{array}$ & $\begin{array}{l}\text { Parcel dos } \\
\text { Abrolhos }\end{array}$ & $\begin{array}{l}\text { Recife } \\
\text { Califórnia }\end{array}$ \\
\hline \multicolumn{5}{|l|}{ Corallinaceae } \\
\hline Hydrolithon boergesenii (Foslie) Foslie & - & $x$ & - & - \\
\hline Lithophyllum kaiseri (Heydrich) Heydrich & $x$ & $x$ & $x$ & $\times$ \\
\hline Lithophyllum sp. & $x$ & $x$ & $x$ & $x$ \\
\hline $\begin{array}{l}\text { Pneophyllum conicum (E. Y. Dawson) Keats, } \\
\text { Y. M. Chamberlain \& M. Baba }\end{array}$ & $x$ & $x$ & $x$ & $x$ \\
\hline Porolithon onkodes (Heydrich) Foslie & $x$ & $\times$ & $x$ & - \\
\hline $\begin{array}{l}\text { Titanoderma prototypum (Foslie) Woelkerling, } \\
\text { Y. M. Chamberlain \& P. C. Silva }\end{array}$ & $x$ & $x$ & $x$ & - \\
\hline \multicolumn{5}{|l|}{ Hapalidiaceae } \\
\hline Lithothamnion crispatum Hauck & $x$ & $x$ & $x$ & - \\
\hline $\begin{array}{l}\text { Melyvonnea erubescens (Foslie) Athanasiadis \& } \\
\text { D. L. Ballantine }\end{array}$ & $x$ & $x$ & $x$ & $x$ \\
\hline \multicolumn{5}{|l|}{ Sporolithaceae } \\
\hline Sporolithon ptychoides Heydrich & $x$ & $\times$ & $x$ & - \\
\hline
\end{tabular}



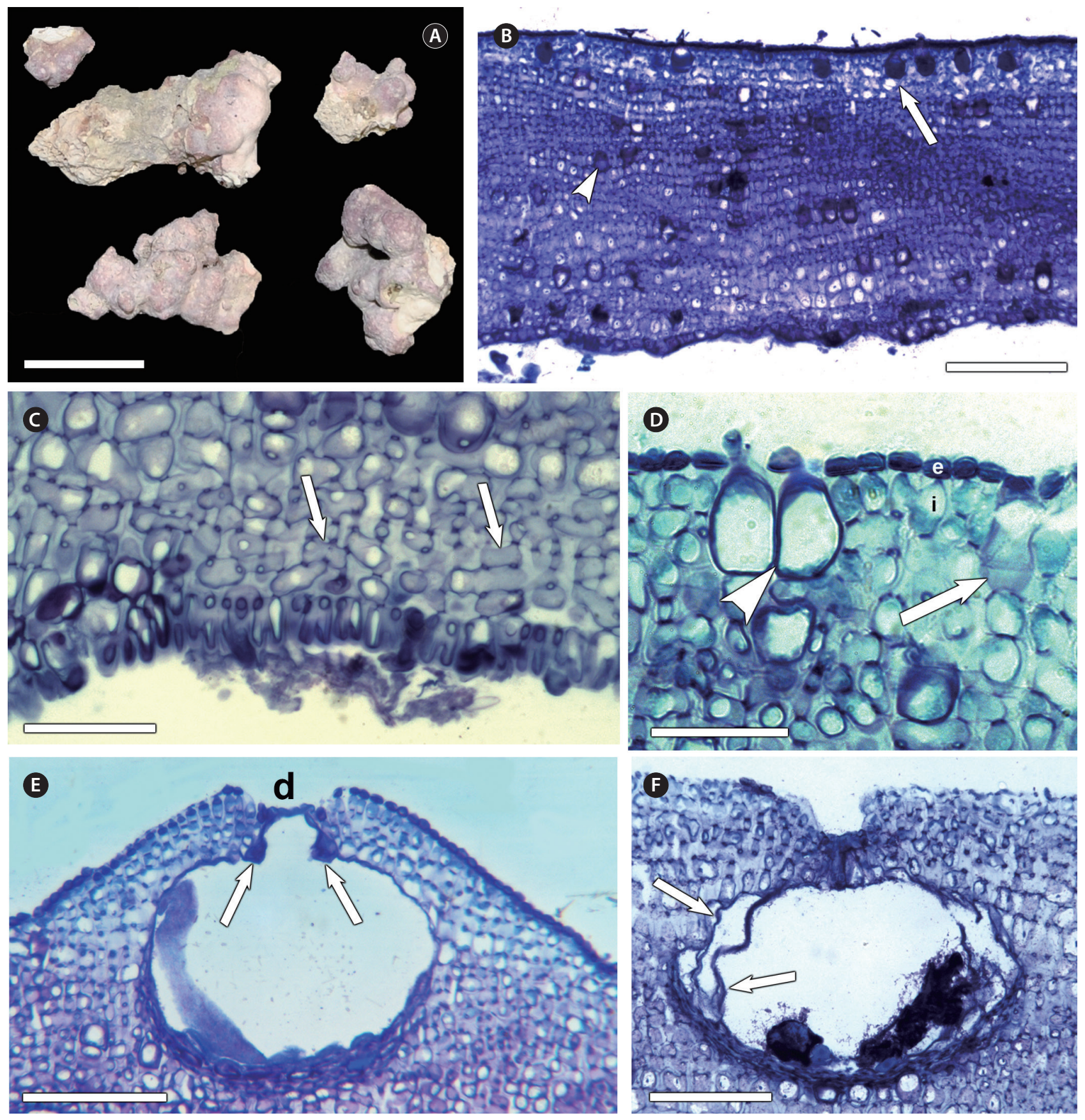

Fig. 2. (A-F) Vegetative and reproductive features of Hydrolithon boergesenii (specimen RB 621493). (A) General view of the specimen with encrusting to lumpy growth form. (B) Section through the vegetative thallus showing the dimerous thallus construction and numerous trichocytes, singly or in pairs, both at the thallus surface (arrow) and buried (arrowhead). (C) Basal portion of the thallus showing its dimerous construction and cell fusions connecting adjacent filaments (arrows). (D) Details of the thallus surface showing rounded or flattened epithallial cells (e), subepithallial initials (i) as long as or longer than their immediate inward derivatives and trichocytes arranged singly (arrow) or in pair (arrowhead). (E) Section through a protruding mature uniporate tetrasporangial conceptacle showing the sunken pore opening (d) and enlarged cells (arrows) lining the base of the pore canal. (F) Section through a young uniporate tetrasporangial conceptacle showing the remains of filaments (arrows) interspersed among the tetrasporangial initials that formed the conceptacle roof. Scale bars represent: $A, 2 \mathrm{~cm} ; B, 170 \mu \mathrm{m} ; C, 60$ $\mu \mathrm{m} ; \mathrm{D}, 50 \mu \mathrm{m} ; \mathrm{E}, 125 \mu \mathrm{m} ; \mathrm{F}, 100 \mu \mathrm{m}$. 
Vegetative and reproductive anatomy. Thallus dimerous (Fig. 2B), basal cells square to elongate (Fig. 2C), erect filaments composed of cells at 7-15 $\mu \mathrm{m}$ in diameter and 5-25 $\mu \mathrm{m}$ in length. Subepithallial initials usually as long as or longer than immediate inward derivatives (Fig. 2D). Epithallial cells occur in a single layer with outer walls rounded or flattened, but not flared (Fig 2D). Cells of adjacent filaments connected by cell fusions; secondary pit connections not observed (Fig. 2C). In large portions of thallus, outline of erect filaments entirely lost due to widespread and extensive cell fusions, giving thallus a distinct appearance in cross-section (Fig. 2B \& C). Trichocytes common, occur singly or in pairs at both thallus surface and buried in thallus (Fig. 2B \& D). Only tetrasporangial thalli observed. Tetrasporangial conceptacles uniporate, raising above surrounding thallus surface (Fig. 2E). Conceptacle chambers are spherical to elliptical, 215-255 $\mu \mathrm{m}$ in diameter and 125-145 $\mu \mathrm{m}$ in height. Floors are located 10-15 cells below surrounding thallus surface. Conceptacle roofs are 5-6 cells thick (including epithallial cells) (Fig. 2E \& F). Conceptacle roofs formed from filaments peripheral to and interspersed among tetrasporangial initials (Fig. 2F). Pores sunken, pore canal lined by a ring of conspicuous, enlarged cells without protruding into pore canal, orientated more-or-less perpendicularly (vertically orientated) to roof surface (Fig. 2E \& F).

Examined specimen. Brazil, Bahia, Abrolhos Archipelago, Ilha de Santa Bárbara, Porto Norte (17 $57^{\prime} 45^{\prime \prime}$ S, $38^{\circ} 41^{\prime} 43^{\prime \prime}$ W, GM Amado-Filho, Oct 23, 2012, RB 621493, as Hydrolithon reinboldii).

Comments. $H$. boergesenii has been previously recorded from Abrolhos reefs in the checklist provided by Figueiredo and Steneck (2000). However, this species is described for the first time in details for the region. The examined specimen of $H$. boergesenii is morphologically (externally) similar to P. onkodes. Anatomically, H. boergesenii can be differentiated from P. onkodes mainly by four anatomical features. $H$. boergesenii has a dimerous thallus construction and a single layer of epithallial cells. It bears trichocytes arranged singly or in pairs. It has uniporate tetrasporangial conceptacles with a sunken pore opening in relation to the surrounding conceptacle roof surface (Maneveldt 2005). On the other hand, P. onkodes possesses a monomerous thallus construction. It has more than one layer of epithallial cells. It bears trichocytes arranged in large, tightly packed horizontal fields. It has uniporate tetrasporangial conceptacles with pore opening at the same level as the surrounding conceptacle roof surface (Maneveldt and Keats 2014). H. borgesenii might have been overlooked in previous studies in Abrol- hos due to its superficial resemblance to $P$. onkodes.

\section{Lithophylloideae Setchell Lithophyllum Philippi \\ Lithophyllum kaiseri (Heydrich) Heydrich}

Habit and ecological observations. Thalli fruticose, attached to corals, NGCA or other biogenic reef structure. Color of living thalli pink to dark red (Fig. 3A). Protuberances with smooth surface, usually compressed, some fused at distal ends (Fig. 3A). This species occurs like smalls shrubs spread along shallow areas (2-5 m depth) of ACS reefs. External appearance and ecological niche similar to those of Lithophyllum sp., making field identification difficult.

Vegetative and reproductive anatomy. Only protuberant branches were sectioned, exhibiting radial internal organization. Since no crustose portion was analyzed, information on thalli construction could not be provided. Vegetative filaments composed of cells at 5-12 $\mu \mathrm{m}$ in diameter and 5-20 $\mu \mathrm{m}$ in length. Subepithallial initials usually as long or longer than immediate inward derivatives (Fig. 3B). Epithallial cells elliptical to rounded, forming a unistratose layer (Fig. 3B). Cells of adjacent filaments joined by secondary pit connections (Fig. 3C). Trichocytes single or in pair, abundantly present in either thallus surface or buried (Fig. 3B). Only tetrasporangial thalli observed. Tetrasporangial conceptacles uniporate, flush or slightly raised above the surrounding thallus surface (Fig. 3D-F). Conceptacle chambers at 200-350 $\mu \mathrm{m}$ in diameter and 115-150 $\mu \mathrm{m}$ in height. Conceptacle roofs formed by 4-6 cells layers (including epithallials) (Fig. 3E \& F). Conceptacle floor located 12-16 cells below surrounding thallus surface. Conceptacle pore canals lined by cells that may protrude laterally into pore canal, not completely occluding canal (canal may be blocked by mucilaginous material) (Fig. 3E \& F). Tetrasporangia formed peripheral to a central columella (Fig. 3E).

Examined specimen. Brazil, Bahia, Abrolhos Archipelago, Ilha de Santa Bárbara, Porto Sul (17 $57^{\prime} 50^{\prime \prime}$ S, $38^{\circ} 42^{\prime} 02^{\prime \prime}$ W, GM Amado-Filho, Oct 24, 2012, RB 623160).

Comments. Hernandez-Kantun et al. (2016) have reassessed the branched Lithophyllum spp. in the Caribben Sea by combining DNA sequencing of type and fieldcollected specimens with morpho-anatomical data and recognized four Lithophyllum species for specimens previously assigned to Lithophyllum congestum (Foslie) (Foslie). Surprisingly, Lithophyllum kaiseri (= Lithophyllum congestum) was confirmed to be widespread through the tropical Indo-West Pacific Oceans, Red Sea, and Ca- 

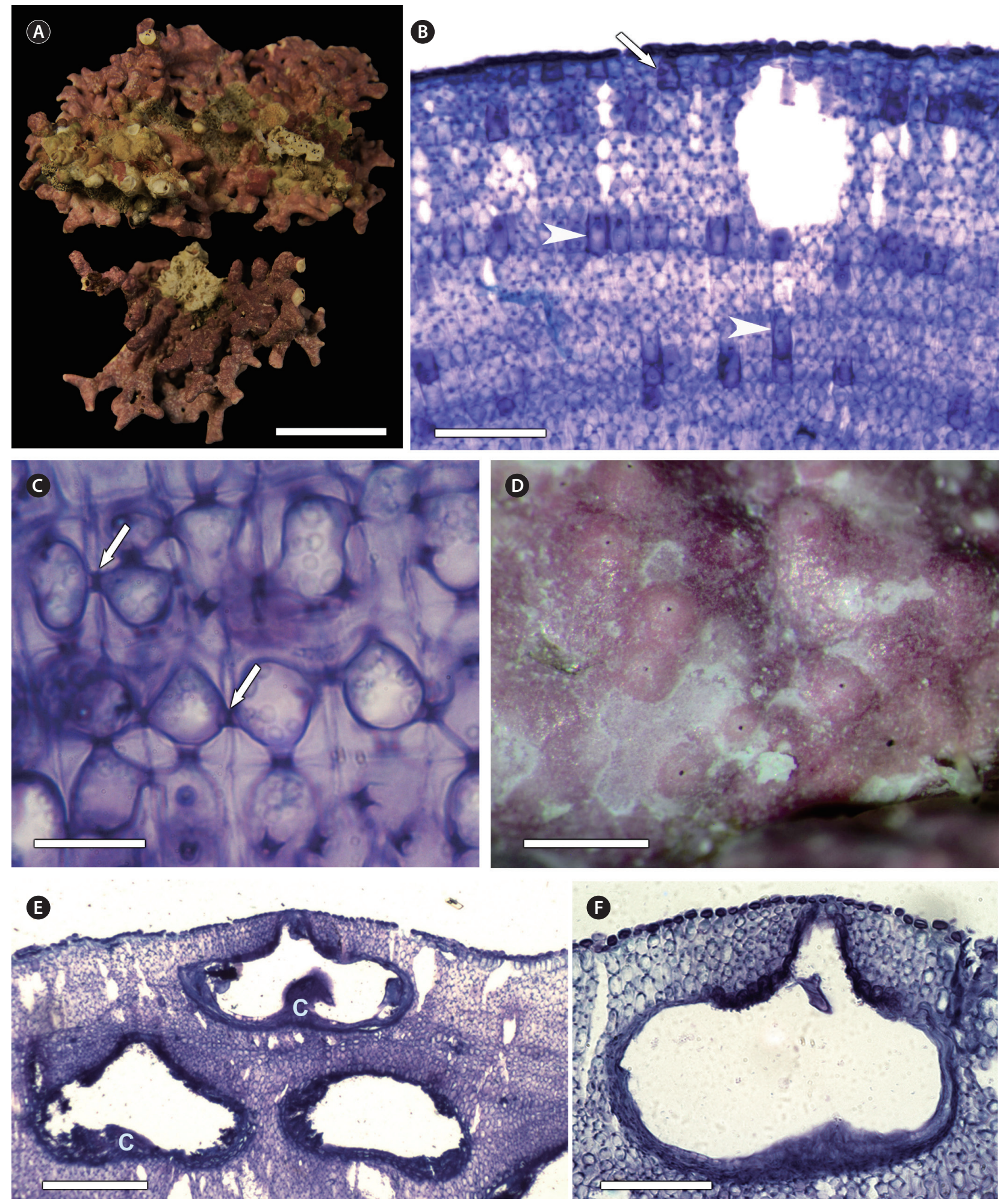

Fig. 3. (A-F) Vegetative and reproductive features of Lithophyllum kaiseri. (A) General view of a fruticose specimen (RB 623160). (B) Transversal section showing trichocytes arranged singly or in pair at the thallus surface (arrow) or buried (arrowheads). (C) Transversal section through the vegetative thallus showing secondary pit connections (arrows). (D) Surface view of flush to slightly raised uniporate tetrasporangial conceptacles. (E) Section through tetrasporangial conceptacles showing central collumela (c) in the center of chamber floor. (F) Longitudinal section showing trasporangial conceptacle roof composed of 4-6 layers of cells and pore canal lined by cells that do not occlude the canal. Scale bars represent: $A$, $2 \mathrm{~cm} ; \mathrm{B}, 60 \mu \mathrm{m} ; \mathrm{C}, 15 \mu \mathrm{m} ; \mathrm{D}, 1 \mathrm{~mm} ; \mathrm{E}, 150 \mu \mathrm{m} ; \mathrm{F}, 65 \mu \mathrm{m}$. 
ribbean Sea. It exhibits identical or nearly identical sequences of both $r b c \mathrm{~L}$ and $p s b \mathrm{~A}$ markers over these regions. L. kaiseri is now being confirmed to be in the South Atlantic by this study (see molecular results), expanding its known geographical distribution. The single specimen (RB 623160) analyzed in the present study with compressed protuberances is morphologically similar to the syntype specimen of Lithophyllum congestum (TRH A231381, S13) illustrated by Hernandez-Kantun et al. (2016, Fig. 5). All other measured morpho-anatomical feautures of $L$. kaiseri from the Abrolhos overlapped with those of species lectotype from the Red Sea (Basso et al. 2015) and L. kaiseri from the Caribbean (Hernandez-Kantun et al. 2016). No central columella was observed in tetrasporangial conceptacles of the lectotype (Basso et al. 2015). However, this structure was preset in either the Brazilian (the present study) or the Caribbean (Hernandez-Kantun et al. 2016) specimens.

\section{Lithophyllum sp.}

Habit and ecological observations. Thalli fruticose, attached to corals of NGCA or other biogenic reef structure. Color of living thalli pink to dark red (Fig. 4A \& B). Protuberances with smooth surface, generally cylindrical, terminating with plump apex, some fused at distal ends (Fig. $4 \mathrm{~A} \& \mathrm{~B}$ ). This species occurs like small shrubs spreading along shallow areas (2-5 m depth) of ACS reefs.

Vegetative and reproductive anatomy. Thallus dimerous, consisting of a single ventral layer of more or less quadratic cells (non-palisade), erect filaments arising perpendicularly to ventral layer (Fig. 4C). Erect filaments composed of cells at 5-11 $\mu \mathrm{m}$ in diameter and 4-20 $\mu \mathrm{m}$ in length. Subepithallial initials usually as long or longer than immediate inward derivatives (Fig. 4D \& E). Epithallial cells elliptical to rounded, forming a unistratose layer (Fig. 4E). Cells of adjacent filaments joined by secondary pit connections (Fig. 4E). Trichocytes single, abundantly present in thallus surface or buried (Fig. 4D). Only tetrasporangial thalli observed. Tetrasporangial conceptacles uniporate, flush or slightly raised above surrounding thallus surface (Fig. 4F \& G). Conceptacle chambers with 330$345 \mu \mathrm{m}$ in diameter and 115-130 $\mu \mathrm{m}$ height. Conceptacle roofs formed by 4-6 cells layers (including epithallials) (Fig. 4G). Conceptacle floor located 9-12 cells below surrounding thallus surface. Conceptacle pore canals lined by cells that may protrude laterally into pore canal, not completely occluding canal (Fig. 4G). Tetrasporangia formed peripheral to a central columella (Fig. 4G).

Examined specimens. Brazil, Bahia, Abrolhos Archi- pelago, Ilha de Santa Bárbara, Porto Norte $\left(17^{\circ} 57^{\prime} 45^{\prime \prime}\right.$ S, $38^{\circ} 41^{\prime} 43^{\prime \prime}$ W, GM Amado-Filho, Oct 23, 2012, RB 623158, RB 623159).

Comments. Lithophyllum sp. is morpho-anatomically similar to L. kaiseri. All traditional features used to distinguish Lithophyllum species are overlapping. It is premature to speculate which characters or combinations of characters may be used to differentiate the two species considering the limited number of specimens analyzed. Further studies using more samples and DNA sequencing could be used to identify diagnostic morphoanatomical features. It is worth noting that we have observed the presence of trichocytes in both L. kaiseri and Lithophyllum sp. Prior to Basso et al. (2014), trichocytes are generally considered as rare or absent in Lithophyllum (Harvey et al. 2009). Hernandez-Kantun et al. (2016) have noted that trichocytes are present in all tropical Red Sea and Caribbean Lithophyllum species, but not in temperate European species. Morphologically speaking, the fruticose growth-form of the branched Lithophyllum sp. and L. kaiseri found in the present study with their cylindrical or compressed protuberances notably resembles that of other Lithophyllum species, including L. affine (Foslie) Foslie, L. kotschyanum, L. neocongestum J. J. Hernandez-Kantun, W. H. Adey \& P. W. Gabrielson, $L$. platyphyllum (Foslie) Foslie, L. pseudoplatyphyllum J. J. Hernandez-Kantun, W. H. Adey \& P. W. Gabrielson L. subplicatum (Foslie) Basso, Caragnano, Le Gall \& Rodondi, $L$. subreduncum Foslie, and L. yemenense Basso, Caragnano, Le Gall \& Rodondi (Basso et al. 2015, Hernandez-Kantun et al. 2016). Anatomically, these species can be distinguished by minor differences in tetrasporangial conceptacle dimensions, number of cells in the conceptacle roof, and depth of the conceptacle chamber floor relative to the thallus surface (Basso et al. 2015, Hernandez-Kantun et al. 2016). Previous studies about ACS reefs have considered that the typical fruticose morphotype of Lithophyllum with cylindrical or compressed protuberances (here reported for Lithophyllum sp. and L. kaiseri) belongs to a single species, i.e., $L$. congestum (currently confirmed to be an heterotypic synonym of L. kaiseri by HernandezKantun et al. 2016) (Figueiredo and Steneck 2000).

\section{Titanoderma Nägeli \\ Titanoderma prototypum (Foslie) Woelkerling, Y. M. Chamberlain \& P. C. Silva}

Habit and ecological observations. Thalli attached, pink to purple with layered growth-form, 2-7 $\mathrm{m}$ in depth. Thallus surface marked by successive layers of applanate 

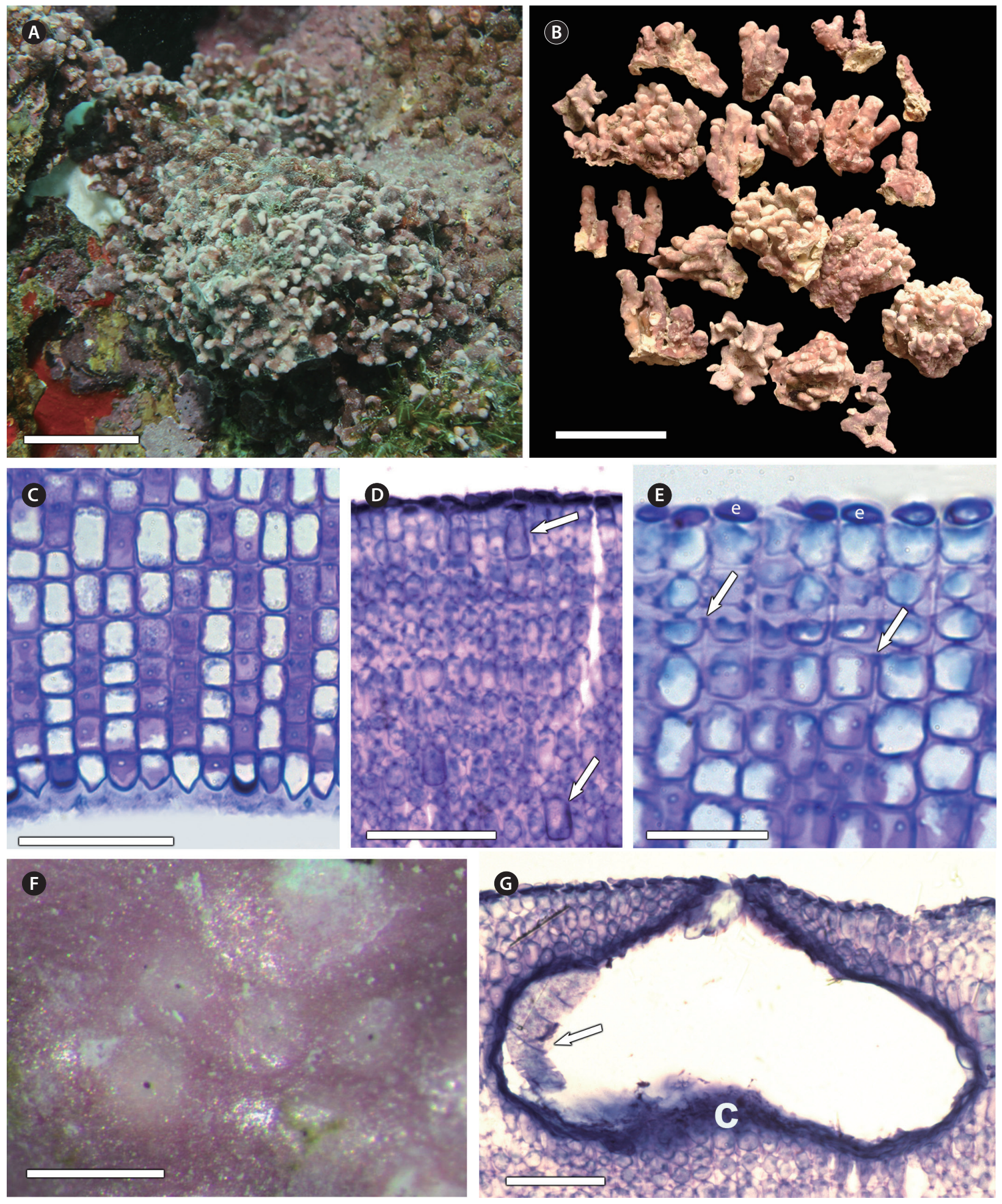

Fig. 4. (A-G) Vegetative and reproductive features of Lithophyllum sp. (A) General view of a fruticose specimen (RB 623158) in the field. (B) Fragments of another fruticose specimen (RB 623159). (C) Basal portion of the thallus showing the dimerous thallus construction. (D) Vertical section showing trichocytes arranged singly at the thallus surface or buried (arrows). (E) Section through the thallus surface showing elliptical to rounded epithallial cells (e) and secondary pit connections (arrows). (F) Surface view of flush to slightly raised uniporate tetrasporangial conceptacles. (G) Section through a tetrasporangial conceptacle showing vestiges of a central collumela (c) and a zonately divided tetrasporangium (arrow) peripherally arranged. Note that the conceptacle pore canal is lined by cells that do not occlude the canal. Scale bars represent: $A, 3 \mathrm{~cm} ; \mathrm{B}, 2 \mathrm{~cm} ; C$ \& G, $50 \mu \mathrm{m} ; \mathrm{D}, 70 \mu \mathrm{m} ; \mathrm{E}, 30 \mu \mathrm{m} ; \mathrm{F}, 500 \mu \mathrm{m}$. 
branches with swirled margins, giving thallus a terraced appearance in surface view (Fig. 5A).

Vegetative and reproductive anatomy. Thallus dimerous, with overlapping layers as a result of secondary growth, resulting in applanate branching. Vegetative thalli consist of a single basal layer of palisade cells, 10$21 \mu \mathrm{m}$ in diameter and $20-40 \mu \mathrm{m}$ in length, and a single layer of epithallial cells, 7-11 $\mu \mathrm{m}$ in diameter and 4-5 $\mu \mathrm{m}$ in length. Applanate branches vertically adjoined to each other (Fig. 5B) or more or less separated (Fig. 5C). Epithallial cells rounded or triangular (Fig. 5B \& C). Basal cells of each branch connected laterally by secondary pit connections (Fig. 5B). Trichocytes not found. Only tetrasporangial plants observed. Tetrasporangial conceptacles uniporate, protruding above surrounding vegetative thallus surface (Fig. 5D). Conceptacle chambers 330-415 $\mu \mathrm{m}$ in diameter and 100-190 $\mu \mathrm{m}$ in height. Conceptacle floor located only one cell below surrounding thallus surface (Fig. 5E). Conceptacle roofs formed by 2-3 cells layers (including epithallials). Conceptacle roof formed from filaments peripheral to and interspersed among tetrasporangial initials. Pore canals lined by cells that may project slightly into canal without completely occluding entire canal. A mucilage plug may occludes pore opening (Fig. $5 \mathrm{~F})$.

Examined specimens. Brazil, Bahia, Caravelas, Parcel das Paredes, Pedra de Leste $\left(17^{\circ} 47^{\prime} 00^{\prime \prime}\right.$ S, 39 $03^{\circ} 05^{\prime \prime}$ W, RG Bahia, Jun 29, 2014, RB 632601). Brazil, Bahia, ACS (1654'36" S, 3840'37" W, GM Amado-Filho, Jul 26, 2009, RB 534878, as Lithophyllum prototypum); Espírito Santo,

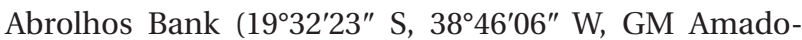
Filho, Nov 20, 2010, RB 525331, as Lithophyllum prototypum).

Comments. Titanoderma prototypum was first reported from the South Atlantic Ocean by Pereira-Filho et al. (2011). However, they did not present a description for this species. Therefore, our finding represents the first documented record of the species from the South Atlantic Ocean. Our specimens morpho-anatomically matched the holotype specimen collected from the US Virgin Islands and Australian collections described in details by Woelkerling and Campbell (1992). The ascription of our specimens into genus Titanoderma rather than to Lithophyllum was based on the predominance of palisade basal cells in thalli following the genus concept proposed by Chamberlain et al. (1991). However, generic boundaries between Titanoderma and Lithophyllum remain controversial and unresolved at both morpho-anatomical level (see discussions in Campbell and Woelkerling 1990, Chamberlain et al. 1991) and genetic level (see discussions in Bailey 1999, Richards et al. 2014). DNA sequencing and phylogenetic analysis of type specimens of Titanoderma pustulatum (Lamouroux) Nägeli and Lithophyllum incrustans Philippi may help validate whether these two genera are separate taxa (Richards et al. 2014).

\section{Metagoniolithoideae H. W. Johansen \\ Pneophyllum Kützing \\ Pneophyllum conicum (E. Y. Dawson) Keats, Y. M. Chamberlain \& M. Baba}

Habit and ecological observations. Thalli attached, encrusting to predominantly warty (Fig. 6A \& B). Color of living thalli pink to purple. Covering large areas of top and walls of reefs at 2-7 $\mathrm{m}$ in depth. Often overgrowing, consequently killing hydrocorals, stony corals, and other NGCA species.

Vegetative and reproductive anatomy. Thallus monomerous with medulla arranged in a coaxial manner (Fig. 6C), filaments (both medullary and cortical) composed of cells 3-11 $\mu \mathrm{m}$ in diameter and 5-25 $\mu \mathrm{m}$ in length. Subepithallial initials usually as long as or longer than immediate inward derivatives (Fig. 6D). Epithallial cells occur in a single layer with outer walls rounded but not flared (Fig. 6D). Cells of adjacent filaments connected by cell fusions. Secondary pit connections not observed (Fig. 6D). Trichocytes are abundant and arranged in large and tightly packed horizontal fields (Fig. 6D). Trichocyte fields not buried. Tetrasporangial and carpogonial (female) thalli observed. Tetrasporangial conceptacles uniporate, raising above surrounding thallus surface (Fig. 6E). Chambers elliptically flattened, 260-360 $\mu \mathrm{m}$ in diameter and 90-115 $\mu \mathrm{m}$ height. Floors located 6-12 cells below surrounding thallus surface. Roofs 5-10 cells thick (including epithallial cells) (Fig. 6E). No conceptacle primordia observed. From orientation of conceptacle roof cells, roof appearing formed from filaments peripheral to and interspersed among tetrasporangial initials. Conceptacle pore canals lined by cells oriented more-or-less parallel or at a sharp angle to roof surface (Fig. 6E). Zonately divided tetrasporangia arranged peripherally to a central columella (Fig. 6 E). Buried conceptacles not found. Carpogonial (female) conceptacles uniporate, raising above surrounding thallus surface (Fig 6F). Chambers $270-300 \mu \mathrm{m}$ in diameter and 70-115 $\mu \mathrm{m}$ in height. Floors located 0-8 cells below surrounding thallus surface. Conceptacle roof with 7-9 layers of cells (including epithallial). Two-celled carpogonial branches terminate in a carpogonium that extends into an elongate trichogyne, may project through pore canal (Fig. 6F). 

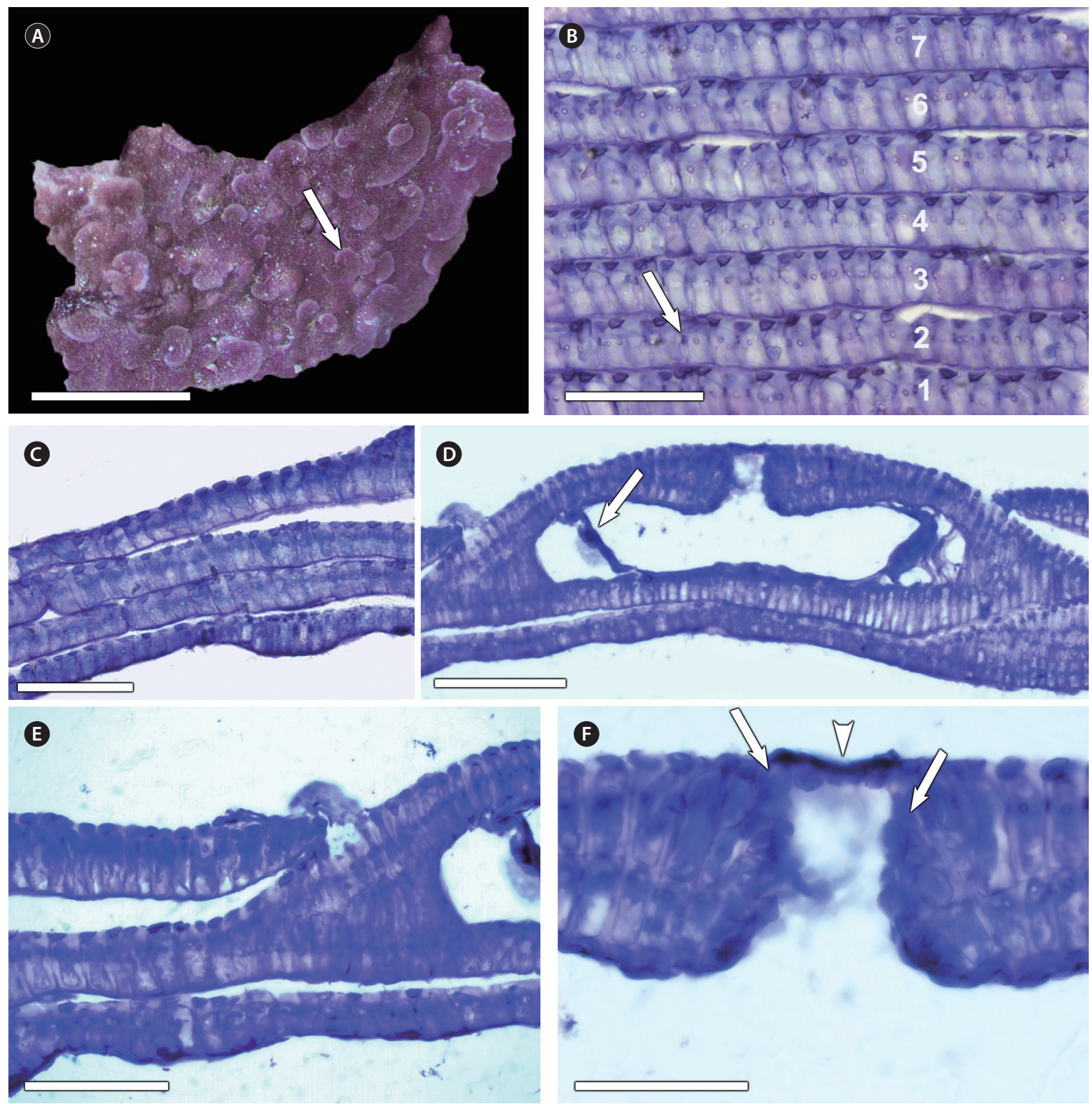

Fig. 5. (A-F) Vegetative and reproductive features of Titanoderma prototypum. (A) Surface view of an encrusting specimen (RB 632601) showing applanate branches with swirled margins (arrow). (B) Section through the thallus showing numerous layers of vertically adjoined applanate branches (1-7). Note that each branch is composed of a basal layer of palisade cells and a layer of dark staining triangular epithallial cells Note also secondary pit connections (arrow) between cells of adjoining filaments. (C) Vertical section of the thallus showing more-or-less separated applanate branches. (D) Longitudinal section through a uniporate tetrasporangial conceptacle. Note the remains of filaments interspersed among the tetrasporangial initials (arrow) originated from the conceptacle roof. (E) Details of the tetrasporangial conceptacle floor located only one cell below the surrounding thallus surface. (F) Details of a tetrasporangial pore canal lined by cells that project slightly into the canal without completely occluding the entire canal (arrows). A mucilage plug occludes the pore opening (arrowhead). Scale bars represent: A, 3 mm; B \& E, 80 $\mu \mathrm{m} ; \mathrm{C}, 100 \mu \mathrm{m} ; \mathrm{D}, 130 \mu \mathrm{m} ; \mathrm{F}, 60 \mu \mathrm{m}$. 

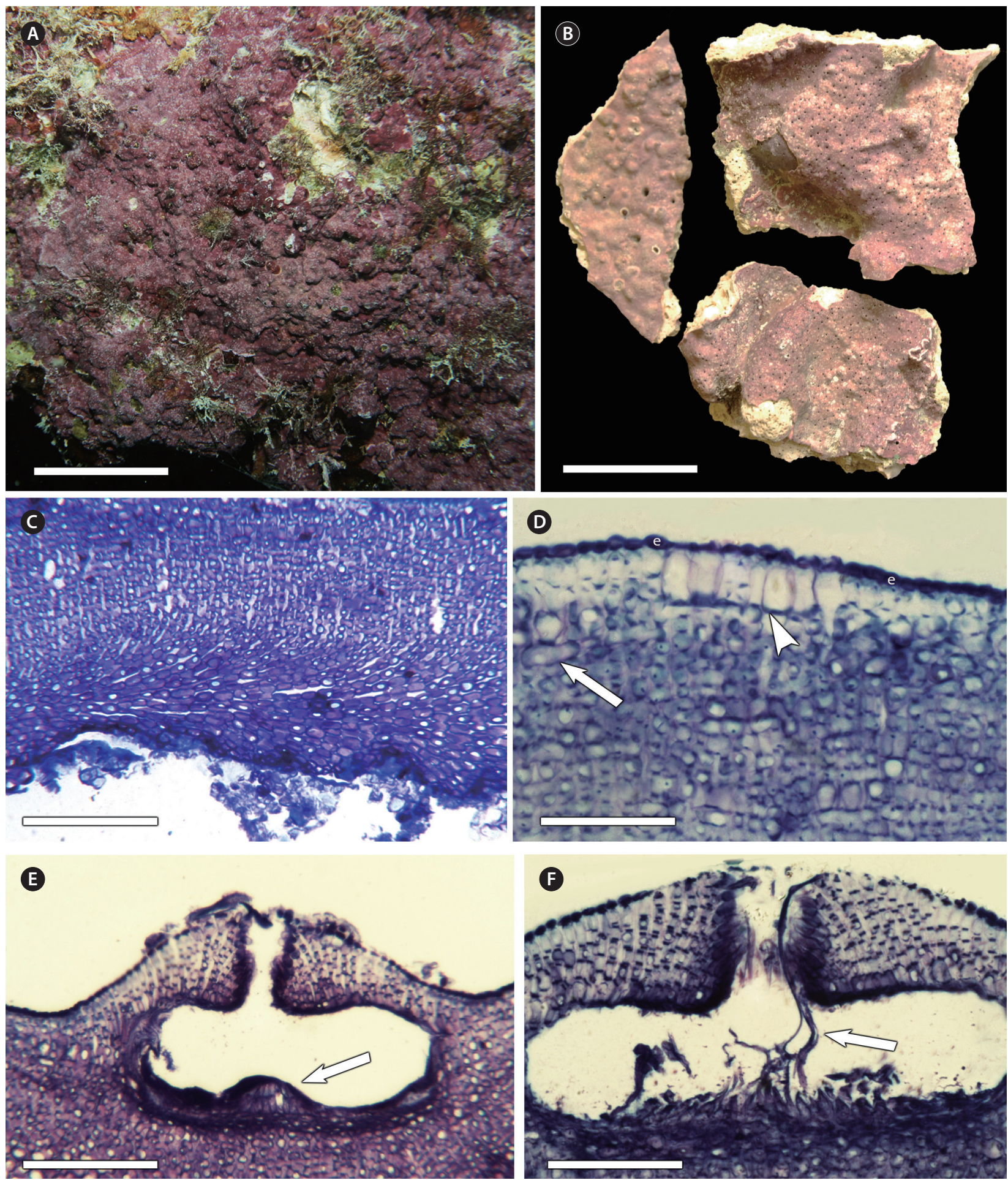

Fig. 6. (A-F) Vegetative and reproductive features of Pneophyllum conicum. (A) Warty specimen (RB 621932) in the field growing on the wall of a pinnacle reef of Parcel dos Abrolhos. (B) Encrusting to warty specimens (RB 621924) collected at $4 \mathrm{~m}$ depth in the Abrolhos Archipelago. (C) Vertical section through the thallus showing monomerous internal construction with a predominantly coaxial medulla. (D) Vertical section through the thallus surface showing rounded epithallial cells (e), cell fusions (arrow), and trichocytes arranged in a large and tightly packed horizontal field (arrowhead). (E) Longitudinal section through a uniporate tetrasporangial conceptacle showing a central columella (arrow). (F) Longitudinal section through a uniporate carpogonial conceptacle showing carpogonial branches at the center of the conceptacle floor, some extends into a trichogyne (arrow) that projects through the conceptacle pore canal. Scale bars represent: $A, 5 \mathrm{~cm} ; B, 2 \mathrm{~cm} ; C, 140 \mu \mathrm{m} ; \mathrm{D}, 70 \mu \mathrm{m} ; \mathrm{E}$, $120 \mu \mathrm{m} ; \mathrm{F}, 75 \mu \mathrm{m}$. 
Examined specimens. Brazil, Bahia, Abrolhos Archipelago, Ilha de Santa Bárbara, Porto Norte $\left(17^{\circ} 57^{\prime} 45^{\prime \prime}\right.$ S, $38^{\circ} 41^{\prime} 43^{\prime \prime}$ W, GM Amado-Filho, Oct 23, 2012, RB 621924, RB 621933; RG Bahia, Jun 24, 2014, RB 621929). Brazil, Bahia, Parcel dos Abrolhos (1759'53" S, 3840'18" W, RG Bahia, Jun 26, 2014, RB 621932).

Comments. Pneophyllum conicum has been reported to be a widespread Indo-Pacific NGCA that can overgrow and kill live coral (Keats et al. 1997, Antonius 2001). This species has been recently reported in Brazil by Mariath et al. (2012) in Porto Seguro, a region about $150 \mathrm{~km}$ north of the ACS. The specimens of Pneophyllum conicum analyzed in this study are morpho-anatomically similar to those described by Mariath et al. (2012). Because of its coral killer behavior, P. conicum could represent a threat to the ACS coral community. Since this species has been positively identified in the ACS reefs, further studies are needed to determine this species' abundance, functional dynamics, and potential threat in this important Atlantic region. In a five-marker molecular phylogeny analysis for family Corallinaceae, Rösler et al. (2016) have found that specimens morpho-anatomically attributed to Pneophyllum (including P. conicum) are distributed in separate clades, concluding that this genus requires reassessment. Pneophyllum conicum should be considered as uncertain genus until unambiguous attribution of DNA sequences to type material or epitypes from the type locality are obtained for this species and the generitype Pneophyllum fragile Kützing (Rösler et al. 2016).

\section{Porolithon Foslie \\ Porolithon onkodes (Heydrich) Foslie}

Habit and ecological observations. Thalli attached, encrusting to lumpy (Fig. 7A) with surface generally smooth. Color of living thalli whitish or pink to purple. Crusts thick $(>1 \mathrm{~mm})$, generally capable of overgrowing thinner ones such as those from T. prototypum (Fig. 7B). Species limited to shallow areas (2-5 m depth) of reef with direct exposure to sunlight. Borer holes frequently seen at thallus surface.

Vegetative and reproductive anatomy. Thallus monomerous and non-coaxial (Fig. 7C), filaments (medullary and cortical) composed of cells $4-13 \mu \mathrm{m}$ in diameter and $6-26 \mu \mathrm{m}$ in length. Subepithallial initials usually as long as or longer than immediate inward derivatives. Epithallial cells occur in 1-3 layers with outer walls elliptical to rounded, but not flared (Fig. 7D). Cells of adjacent filaments connected by cell fusions; secondary pit connections not observed. Trichocytes abundant and arranged in large and tightly packed horizontal fields at thallus surface (Fig. 7C) or buried in thallus (Fig. 7C \& D). Only tetrasporangial thalli observed. Tetrasporangial conceptacles uniporate, more-or-less flush, only slightly raising above surrounding thallus surface. Conceptacle chambers elliptical, 220-230 $\mu \mathrm{m}$ in diameter and 100-120 $\mu \mathrm{m}$ in height. Floors located 10-17 cells below surrounding thallus surface. Conceptacle roofs 4-6 cells thick (including epithallial cells) (Fig. 7F). Conceptacle primordia not observed. From orientation of conceptacle roof cells, roof appearing formed from filaments peripheral to and interspersed among tetrasporangial initials. Conceptacle pore canals lined by a ring of conspicuous and enlarged cells that do not protrude into pore canal, orientated more-orless perpendicularly (vertically orientated) to roof surface (Fig. 7F).

Examined specimen. Brazil, Bahia, Parcel das Paredes, Pedra de Leste $\left(17^{\circ} 47^{\prime} 00^{\prime \prime}\right.$ S, $39^{\circ} 03^{\prime} 05^{\prime \prime}$ W, RG Bahia, Jun 29 , 2014, RB 623155).

Comments. According to Maneveldt and Keats (2014), P. onkodes is one of the most widespread tropical to subtropical NGCA. Although generally encrusting to smooth surfaced, it has a various morphologies largely resulting from grazing. Porolithon onkodes (as P. pachydermum) has been cited by Figueiredo and Steneck (2000) and Tâmega et al. (2014) as one of the dominant NGCA species in the shallow reefs of the ACS.

\section{Hapalidiales W. A. Nelson, J. E. Sutherland, T. J. Farr \& H. S. Yoon in Nelson et al. Hapalidiaceae J. E. Gray Melobesioideae Bizzozero Lithothamnion Heydrich Lithothamnion crispatum Hauck}

Habit and ecological observations. Thalli attached or free-living, lumpy to fruticose (Fig. 8A). In most cases, protuberances short and nodular (Fig. 8A). Color of living thalli pink to purple.

Vegetative and reproductive anatomy. Thallus monomerous non-coaxial (Fig. 8B), filaments (both medullary and cortical) composed of cells at 6-15 $\mu \mathrm{m}$ in diameter and 6-35 $\mu \mathrm{m}$ in length. Subepithallial initials usually as long or longer than immediate inward derivatives (Fig. 8C). Epithallial cells with distal walls flattened and flared, disposed in a single layer (Fig. 8C). Cells of adjacent filaments connected by cell fusions (Fig. 8C). Trichocytes not found. Only tetrasporangial plants observed. Tetrasporangial conceptacles multiporate, protruding above surrounding vegetative thallus surface (Fig. 8D). Concep- 

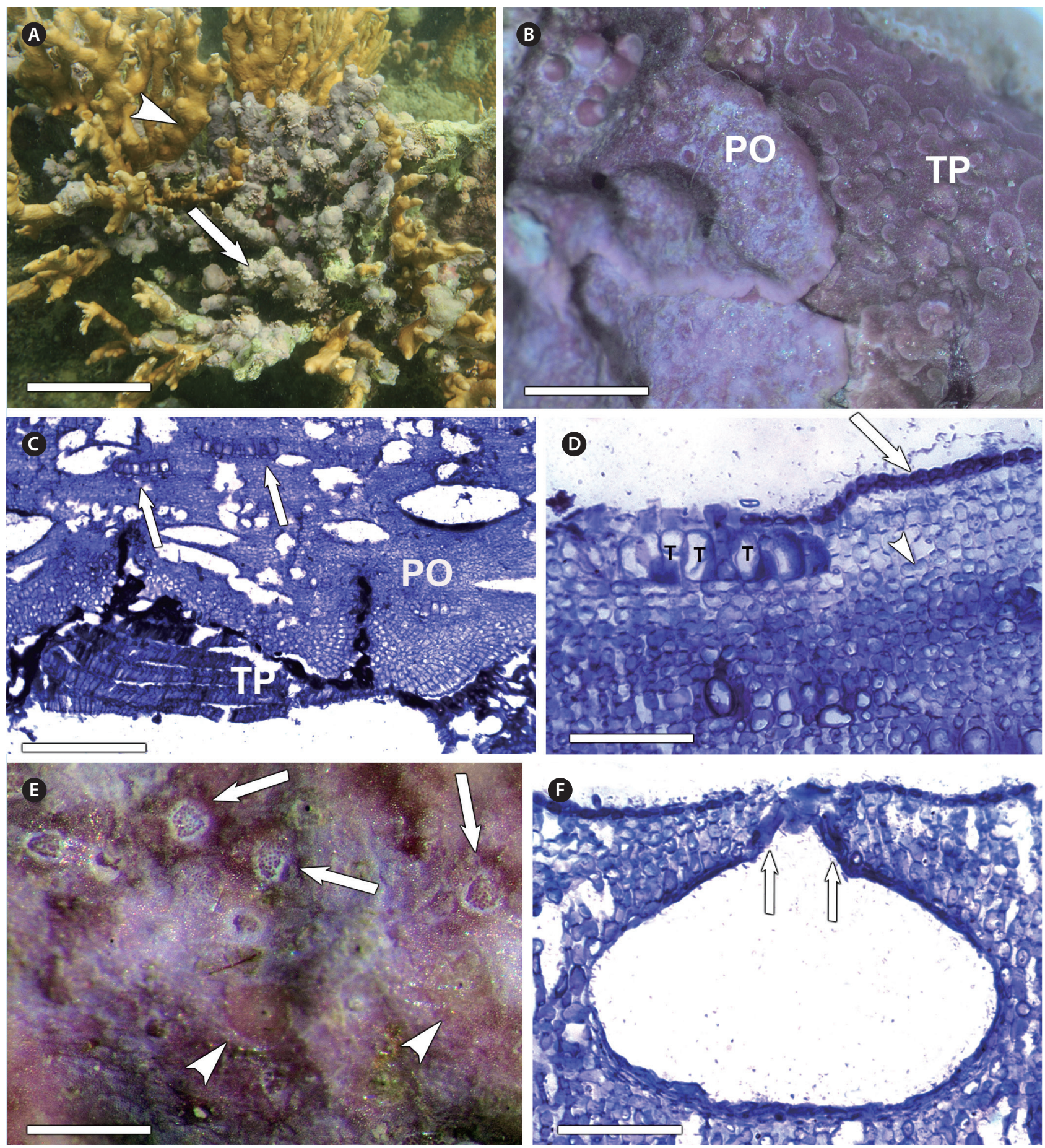

Fig. 7. (A-F) Vegetative and reproductive features of Porolithon onkodes (specimen RB 623155). (A) Specimen in the field (arrow) covering the hydrocoral Millepora alcicornis (arrowhead). (B) Porolithon onkodes (PO) on Titanoderma prototypum (TP). (C) Vertical section through the thallus showing monomerous and non-coaxial construction. Note buried trichocytes arranged in large and tightly packed horizontal fields (arrows). Note also that the thallus of Porolithon onkodes (PO) is on the top of a thallus of Titanoderma prototypum (TP). (D) Vertical section through the thallus surface showing elliptical to rounded epithallial cells occurring in multiple layers (arrow), cell fusions (arrowhead), and a tightly packed horizontal field of trichocytes (T). (E) Thallus surface showing trichocyte fields (arrows) and more-or-less flush to slightly raised uniporate tetrasporangial conceptacles (arrowheads). (F) Section through a uniporate tetrasporangial conceptacle showing enlarged cells (arrows) lining the base of the pore canal. Scale bars represent: A, $5 \mathrm{~cm} ; \mathrm{B}, 3 \mathrm{~mm} ; \mathrm{C}, 250 \mu \mathrm{m} ; \mathrm{D}, 75 \mu \mathrm{m} ; \mathrm{E}, 500 \mu \mathrm{m} ; \mathrm{F}, 70 \mu \mathrm{m}$. 

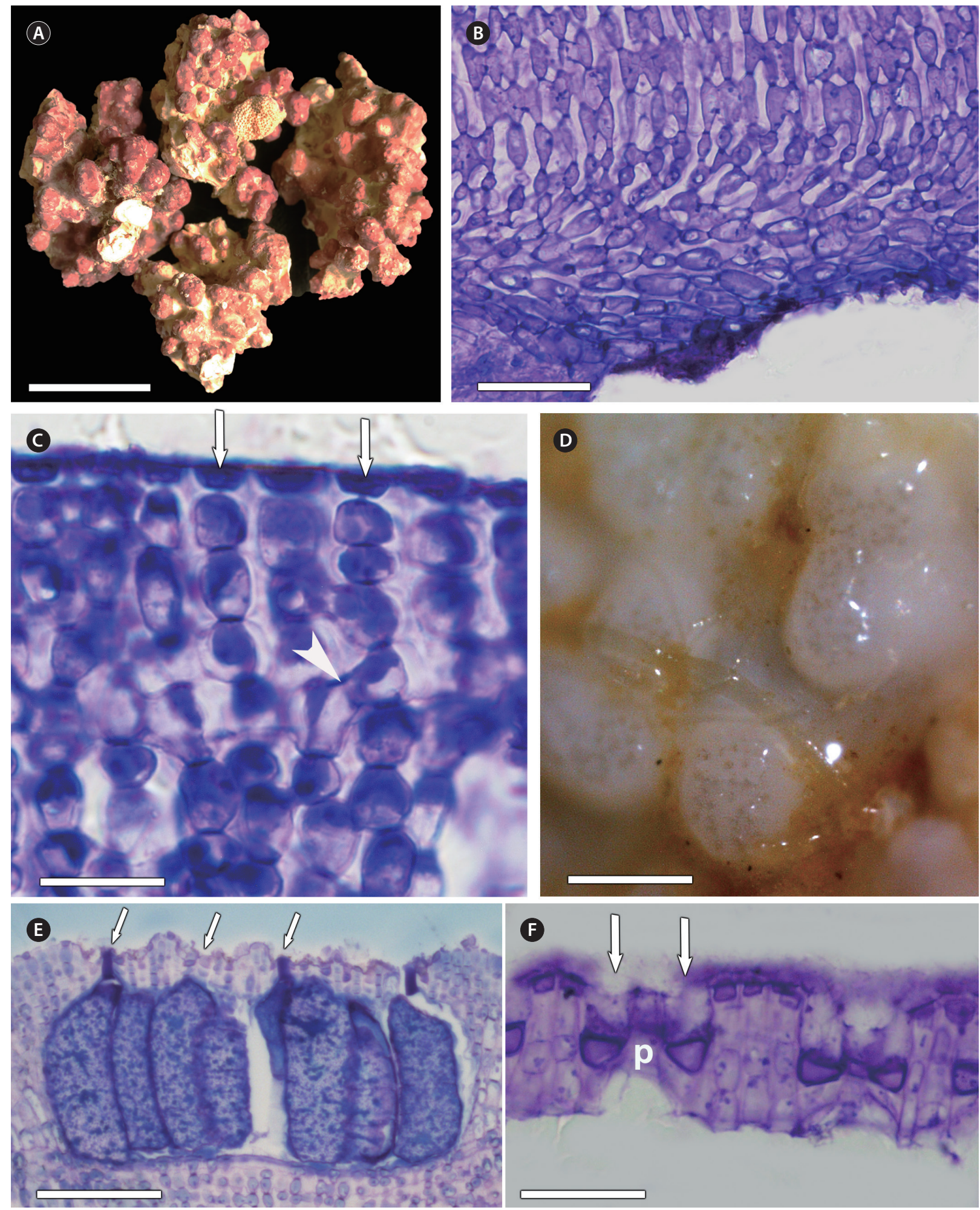

Fig. 8. (A-F) Vegetative and reproductive features of Lithothamnion crispatum. (A) General view of a lumpy specimen (RB 623157). (B) Section through the thallus showing monomerous and non-coaxial thallus construction. (C) Section through the thallus surface showing flared epithallial cells (arrows) and cell fusions (arrowhead) connecting adjacent filaments. (D) Surface view showing multiporate tetrasporangial conceptacles. (E) Section through a multiporate conceptacle showing zonately divided tetrasporangia distributed across the chamber floor. Note that conceptacle roof is pitted with depressions (arrows) resulting from disintegration of rosette cells surrounding the pores. (F) Details of depressions (arrows) surrounding pore canal (p) in conceptacle roof. Scale bars represent: $A, 2 \mathrm{~cm} ; B, 30 \mu \mathrm{m} ; C, 15 \mu \mathrm{m} ; \mathrm{D}, 500 \mu \mathrm{m} ; \mathrm{E}, 75 \mu \mathrm{m} ; \mathrm{F}, 20 \mu \mathrm{m}$. 
tacle chambers at 250-450 $\mu \mathrm{m}$ in diameter and 140-200 $\mu \mathrm{m}$ in height. Conceptacle floor located 8-12 cells below surrounding thallus surface. Roof filaments 3-5 cells long (including epithallials) (Fig. 8E). Roofs of mature conceptacles pitted with depressions (Fig. 8E \& F) resulting from disintegration of rosette cells surrounding pores. Filaments lining pore canal composed of cells differing in size and shape from other roof cells (Fig. 8F).

Examined specimens. Brazil, Bahia, Abrolhos Archipelago, Ilha de Santa Bárbara, Porto Norte $\left(17^{\circ} 57^{\prime} 45^{\prime \prime}\right.$ S, $38^{\circ} 41^{\prime} 43^{\prime \prime}$ W, GM Amado-Filho, Oct 23, 2012, RB 623157; Oct 26, 2012, RB 623156).

Comments. The specimens of $L$. crispatum found in this study showed unique tetrasporangial conceptacle roof structure pitted with depressions which were considered as diagnostic features of this species (Basso et al. 2011). These features are displayed when observing multiporate conceptacles under stereoscopy microscope, usually dispensing anatomical sectioning for species identification. L. crispatum has been previously recorded in Brazil only as free-living rhodoliths (Bahia et al. 2010, Da Nóbrega Farias et al. 2010, Bahia 2014). This is the first time that this species is found to grow attached on a reef in Brazil.

\section{Melyvonnea Athanasiadis \& D. L. Ballantine Melyvonnea erubescens (Foslie) Athanasiadis \& D. L. Ballantine}

Habit and ecological observations. Thalli fruticose, pink to red in color (Fig. 9A). Most protuberances cylindrical with rounded apex (Fig. 9A) being ramified and / or anastomosing. This species occurs like smalls shrubs spreading along shallow areas (2-5 m) of Abrolhos reefs.

Vegetative and reproductive anatomy. Thallus monomerous with coaxial medula (Fig. 9B), filaments (medullary and cortical) composed of cells at $4-10 \mu \mathrm{m}$ in diameter and 7-30 $\mu \mathrm{m}$ in length. Subepithallial initials usually as long or longer than immediate inward derivatives (Fig. 9C). Epithallial cells rounded or flattened and disposed in a single layer (Fig. 9C). Cells of adjacent filaments connected by cell fusions (Fig. 9C). Trichocytes not found. Only tetrasporangial plants observed. Tetrasporangial conceptacles multiporate, flat topped, protruding above surrounding vegetative thallus surface (Fig. 9D \& E). Conceptacle chambers at 315-400 $\mu \mathrm{m}$ in diameter and 150-200 $\mu \mathrm{m}$ in height, commonly filled with large sterile vegetative cells. Roof filaments 4-7 cells long (including epithallial cells), formed by filaments peripheral to and interspersed amongst tetrasporangial initials. Filaments lining pore canals composed of 3 to 5 cells. More elongate than other roof cells, especially near base of pore (Fig. 9F).

Examined specimen. Brazil, Bahia, Abrolhos Archipelago, Ilha de Santa Bárbara, Porto Norte $\left(17^{\circ} 57^{\prime} 45^{\prime \prime} \mathrm{S}\right.$, $38^{\circ} 41^{\prime} 43^{\prime \prime}$ W, GM Amado-Filho, Oct 23, 2012, RB 621495, as Mesophyllum erubescens).

Comments. M. erubescens is the only species of Melyvonnea recorded from Brazil. The ascription of our specimens into genus Melyvonnea is based on the following combined features: fruticose thalli with branched protuberances, predominantly coaxial, medulla and filaments lining canals of multiporate roofs composed of 3 to 5 cells with distinctively elongate basal cells (Athanasiadis and Ballantine 2014). Other features related to gametophytes and carposporophytes complement the genus diagnosis. However, these life stages were not investigated here. Beyond M. erubescens, genus Melyvonnea is represented by other three species, namely M. aemulans (Foslie \& M. Howe) Athanasiadis \& D. L. Ballantine, M. canariensis (Foslie) Athanasiadis \& D. L. Ballantine (type species), and M. madagascariensis (Foslie) Athanasiadis \& D. L. Ballantine. M. erubescens can be distinguished from these species mainly by the number of cells lining the tetrasporangial pore canal and the distribution of spermatangia on male conceptacles (floor or floor and roofs) (Athanasiadis and Ballantine 2014).

\section{Sporolithales Le Gall, Payri, Bittner \& G. W. Saunders Sporolithaceae E. Verheij Sporolithon Heydrich Sporolithon ptychoides Heydrich}

Habit and ecological observations. Thalli attached, pink to purple with encrusting to warty growth-form (Fig. 9A). Species mostly found in shading environments protected from direct sunlight exposure.

Vegetative and reproductive anatomy. Thallus monomerous non-coaxial (Fig. 10B), filaments composed of cells at $5-11 \mu \mathrm{m}$ in diameter and $8-23 \mu \mathrm{m}$ in length. Subepithallial initials usually with same size as immediate inward derivatives (Fig. 10C). Epithallial cells with distal walls flared and disposed in a single layer (Fig. 10C). Cells of adjacent filaments joined by both secondary pit connections and cell fusions with a ratio of 2:1. Trichocytes not found. Only tetrasporangial plants observed. Tetrasporangia formed within calcified compartments grouped into sorus (Fig. 10D-F). Sori raised 2-4 layers of cells above surrounding vegetative thallus surface (Fig. 10D). Tetrasporangial compartments elliptical to rounded at 43-50 $\mu \mathrm{m}$ in diameter and 75-100 $\mu \mathrm{m}$ in height (Fig. 

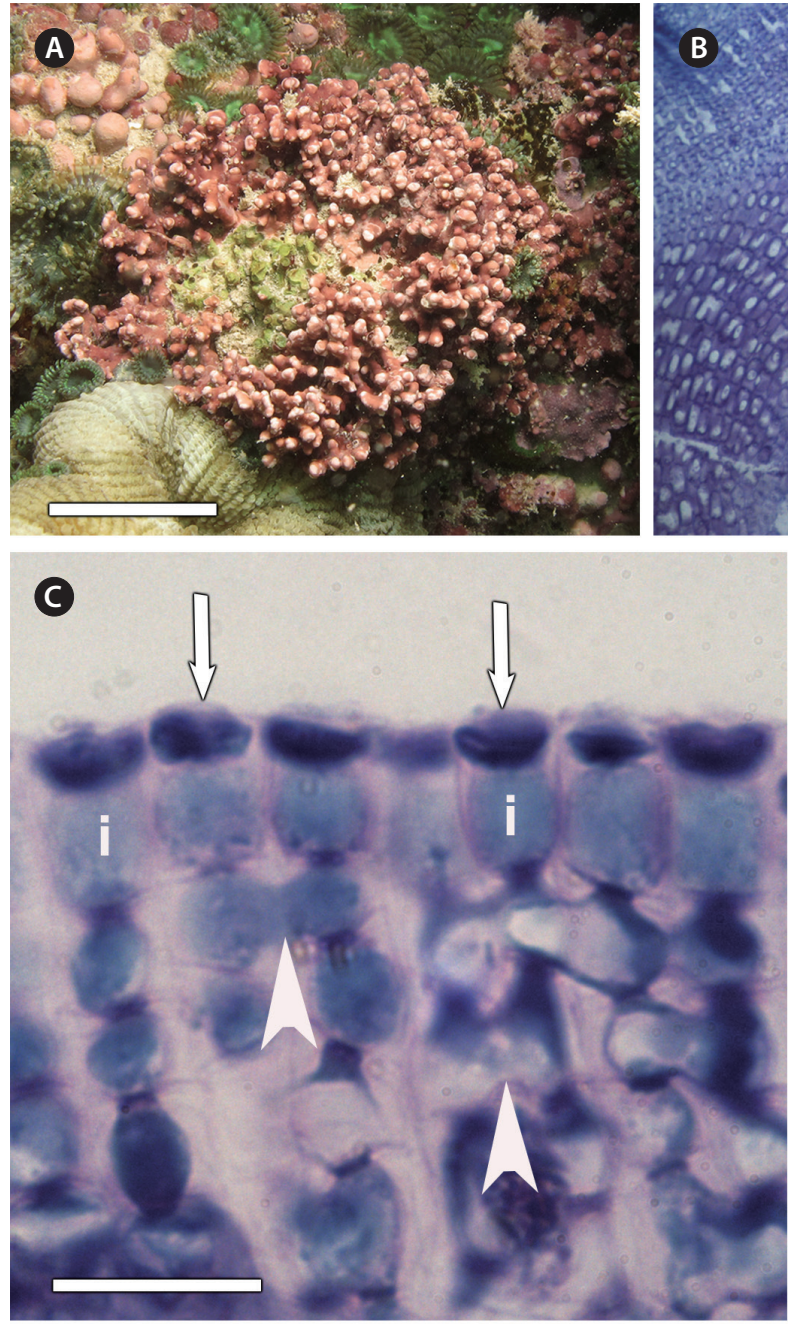

E

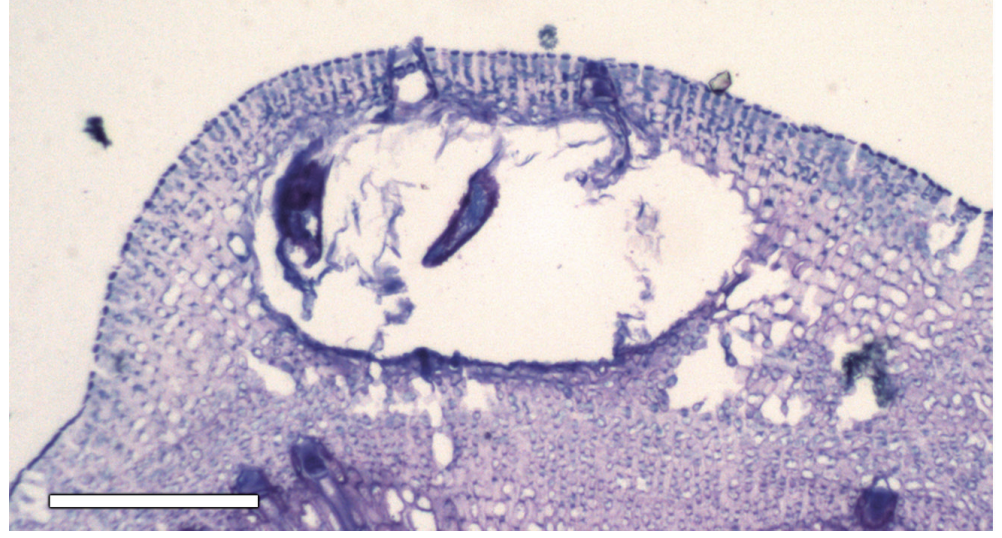

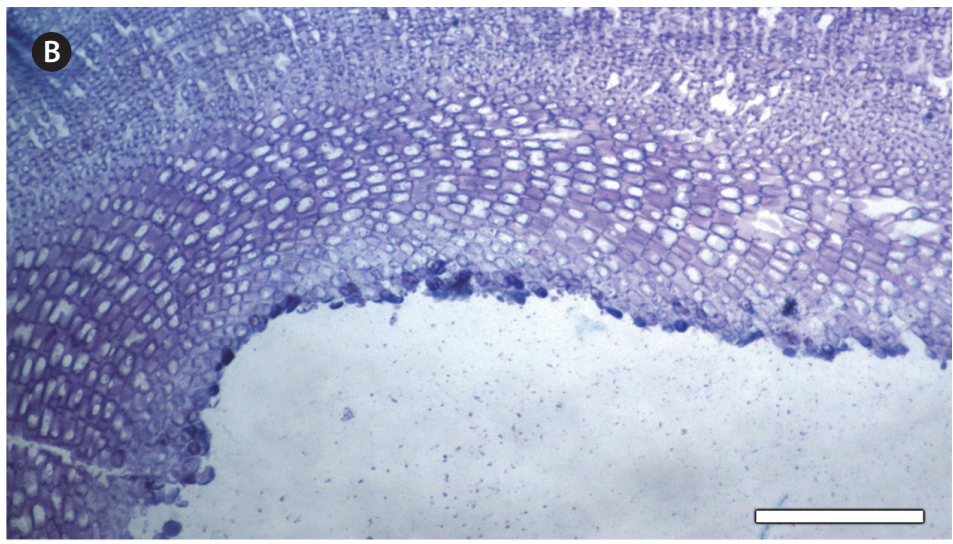
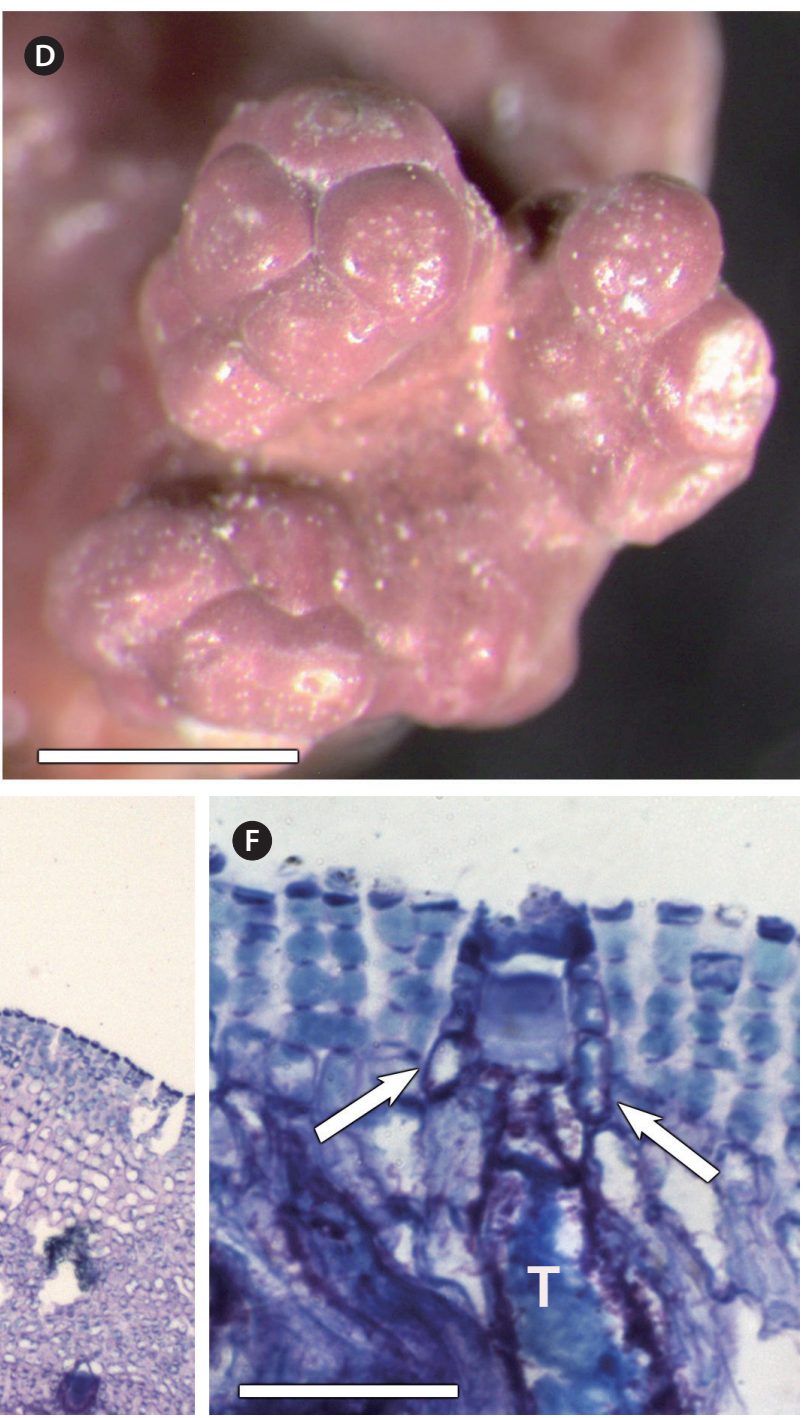

Fig. 9. (A-F) Vegetative and reproductive features of Melyvonnea erubescens. (A) General view of a fruticose specimen (RB 621495) in the field. (B) Section through the thallus showing the coaxial and monomerous thallus construction. (C) Section through the thallus surface showing rounded epithallial cells (arrows) and subepithallial initials (i) as long as or longer than their immediate inward derivatives and cell fusions (arrowheads) connecting adjacent filaments. (D) Surface view of flat topped multiporate tetrasporangial conceptacles. (E) Section through a multiporate conceptacle showing remnants of tetrasporangia within the chamber. (F) Details of the filaments lining the tetrasporangial conceptacle pore canal. Note that they are composed of cells different from other roof cells. They are consisted of cells that are more elongate, especially near the base of the pore canal (arrows). Note also remains of a tetrasporangium (T). Scale bars represent: $A, 4 \mathrm{~cm} ; B$ \& E, $150 \mu \mathrm{m} ; C, 15 \mu \mathrm{m} ; \mathrm{D}, 1 \mathrm{~mm} ; \mathrm{F}, 40 \mu \mathrm{m}$. 

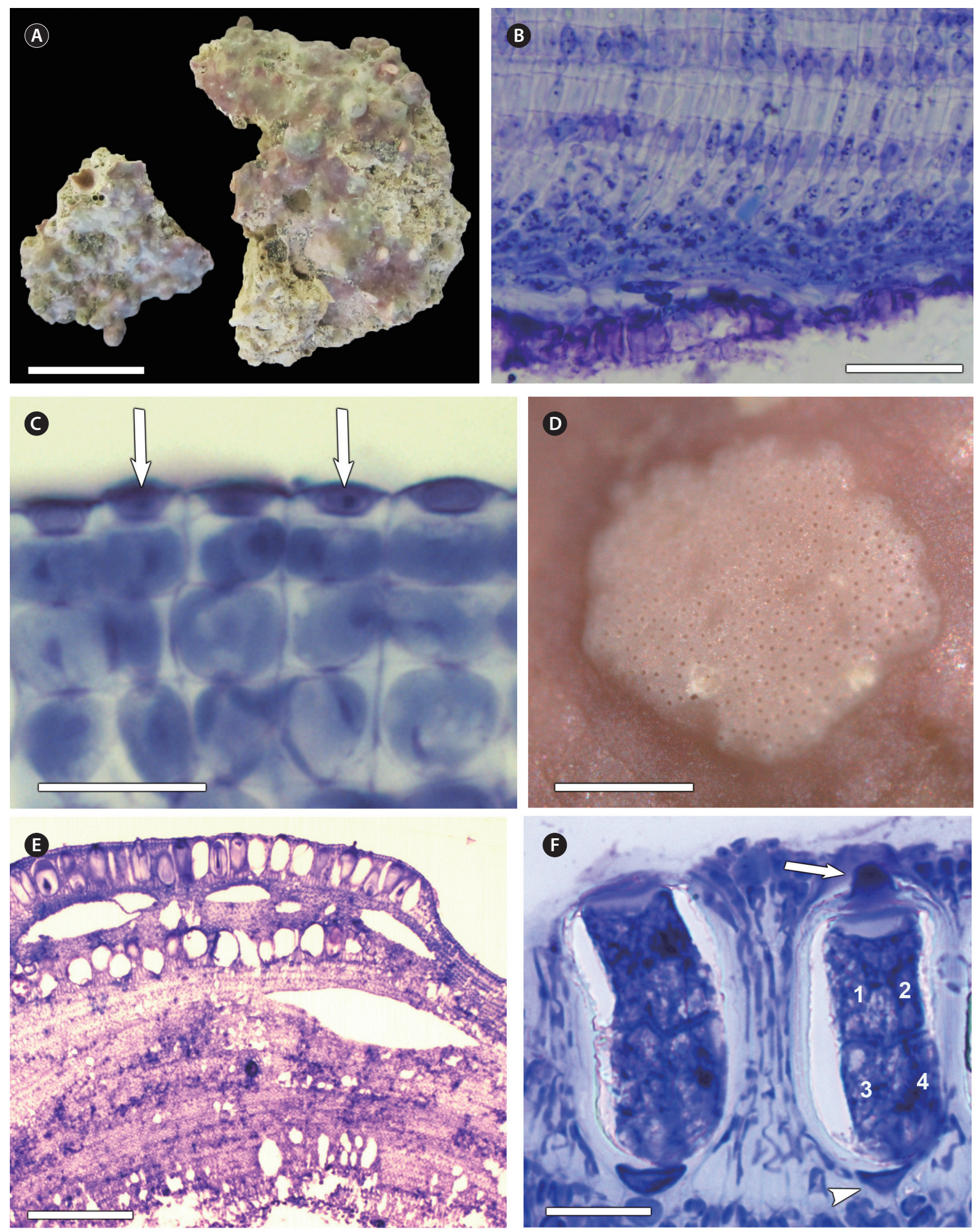

Fig. 10. (A-F) Vegetative and reproductive features of Sporolithon ptychoides. (A) General view of an encrusting to warty specimen (RB 621750). (B) Section through the thallus showing monomerous and non-coaxial thallus construction. (C) Section through the thallus surface showing epithallial cells (arrows) with flared distal walls. (D) Surface view of a raised sorus. (E) Vertical section through the thallus showing old buried and empty tetrasporangial compartments. (F) Longitudinal section through two tetrasporangial compartments showing a tetrasporangium with cruciately divided tetraspores (1-4) with pore plug (arrow) and single stalk cell at the base of tetrasporangium (arrowhead). Scale bars represent: $A$, $1.5 \mathrm{~cm} ; \mathrm{B}, 60 \mu \mathrm{m} ; \mathrm{C}, 20 \mu \mathrm{m} ; \mathrm{D}, 0.5 \mathrm{~cm} ; \mathrm{E}, 200 \mu \mathrm{m} ; \mathrm{F}, 30 \mu \mathrm{m}$. 
$10 \mathrm{E} \& \mathrm{~F})$, separated from each other by 1-3 calcified filaments (paraphyses), bearing 3-5 cells each with a basal layer of elongated cells (Fig. 10F). Tetrasporangia cruciately divided, with apical plugs, supported by a single stalk cell (Fig. 10F). Senescent tetrasporangial compartments buried in thallus (Fig. 10E).

Examined specimen. Brazil, Bahia, Abrolhos Archipelago, Ilha de Santa Bárbara, Porto Norte (17 $57^{\prime} 45^{\prime \prime}$ S, $38^{\circ} 41^{\prime} 43^{\prime \prime}$ W, GM Amado-Filho, Oct 23, 2012, RB 621750).

Comments. The samples of Sporolithon ptychoides identified here are morpho-anatomically in accordance with the type collection of this species found in the Red Sea (Verheij 1993) as well as with previous records of this species collected from Brazil (Bahia et al. 2011, Henriques et al. 2014). However, in these previous records, $S$. ptychoides was found only in free-living (rhodolith) habit. This is the first time that S. ptychoides is found as attached crust in Brazil.

\section{Molecular results}

This study generated 16 sequences from nine morphoanatomically identified species (Supplementary Table S1). The resulting phylogenetic tree from concatenated ML and NJ analyses are shown in Fig. 11.

The $p s b \mathrm{~A}$ sequence from the material identified as $L$. kaiseri (RB 623160) from Abrolhos was identical to those from conspecific specimens collected from Madagascar, Martinique, and Australia, forming a fully supported clade (100\% BS in both analysis, NJ and ML). As these specimens had their $r b c \mathrm{~L}$ sequences matching those from type material of L. kaiseri (Hernandez-Kantum et al. 2016), the presence of $L$. kaiseri in Abrolhos is confirmed. Two $p s b \mathrm{~A}$ sequences corresponding to branched species Lithophyllum sp. from Abrolhos formed an isolated clade (97/98\% BS) within the low supported clade that grouped others branched species of Lithophyllum (L. yemenense, L. neocongestum, L. platyphyllum, and L. pseudoplatyphyllum). This suggests that Lithophyllum sp. corresponds to a new species. However, further investigations including analyses of more specimens are needed before proposing it as a new species.

M. erubescens was another species whose identification was confirmed based on indirect DNA sequences comparison with type material. The $p s b \mathrm{~A}$ sequence of M. erubescens from Abrolhos was identical to those of topotype material (KM 983035 and KM 983036) collected from Fernando de Noronha (Brazil) with $r b c \mathrm{~L}$ sequences matching those of species holotype used in Sissini et al. (2014).
The specimen identified as T. prototypum (RB 632601) from Abrolhos and T. pustulatum from New Zealand did not form a monophyletic clade. Instead, they grouped with other Lithophyllum species, suggesting that the morpho-anatomical features used to distinguish these genera (e.g., presence or absence of palisade cells in basal filaments) should be reviewed or at least these genera should be placed as synonym as previously proposed (Campbell and Woelkerling 1990). Whether Titanoderma and Lithophyllum are distinct genera remain unclear. DNA sequences of type / topotype material of theirs type species (T. pustulatum and L. incrustans) are needed for comparison.

The material identified in this study as Porolithon onkodes from Abrolhos formed a clade with P. onkodes from Indonesia with moderate to strong support (87/97\% BS). Porolithon onkodes from Japan was isolated in another clade with full support, suggesting that the Brazilian and Indonesian specimens correspond to species different from that of Japan. Pneophyllum conicum from Abrolhos formed a clade with Pneophyllum conicum from Japan and Australia with strong support (99/99\% BS). However, within this clade, four Pneophyllum conicum specimens from Abrolhos formed an independent clade with high support (90/93\% BS). Specimen identified as H. boergesenii (RB 621493) grouped with H. boergesenii from El Salvador, Phillippines, and Guadeloupe with high support (80/95\% BS). The sequence from specimen identified as S. ptychoides from Abrolhos (RB 621750) was identical to two others (KC 870926 and KC 870927) from Fernando de Noronha Island of northeastern Brazil.

Specimens of L. crispatum from ACS (RB 623156 and 623157) grouped with a specimen of $L$. crispatum from Balearic Sea (KJ 710356) (87/88\% BS) which was collected relatively close $(\sim 1,000 \mathrm{~km}$ away) to the type locality of L. crispatum, Adriatic Sea. However, L. crispatum from New Zealand formed an isolate clade with strong support $(98 / 100 \% \mathrm{BS})$, suggesting that it is a different species. Both attached (encrusting) (RB 623157) and free-living (RB 623156) L. crispatum specimens from Abrolhos were grouped into the same clade. Specimens of S. ptychoides from Abrolhos (RB 621750, attached) and Fernando de Noronha (KC 870926, KC 870927, free-living) had identical $p s b$ A sequences. Hernández-Kantún et al. (2015) have also observed that rhodolith-forming individuals are genetically similar to encrusting forms in the genera Lithothamnion, Phymatolithon, Mesophyllum, Hydrolithon, Spongites, and Sporolithon, concluding that rhodolith habit cannot be used to delimit species for taxonomic or identification purposes. 


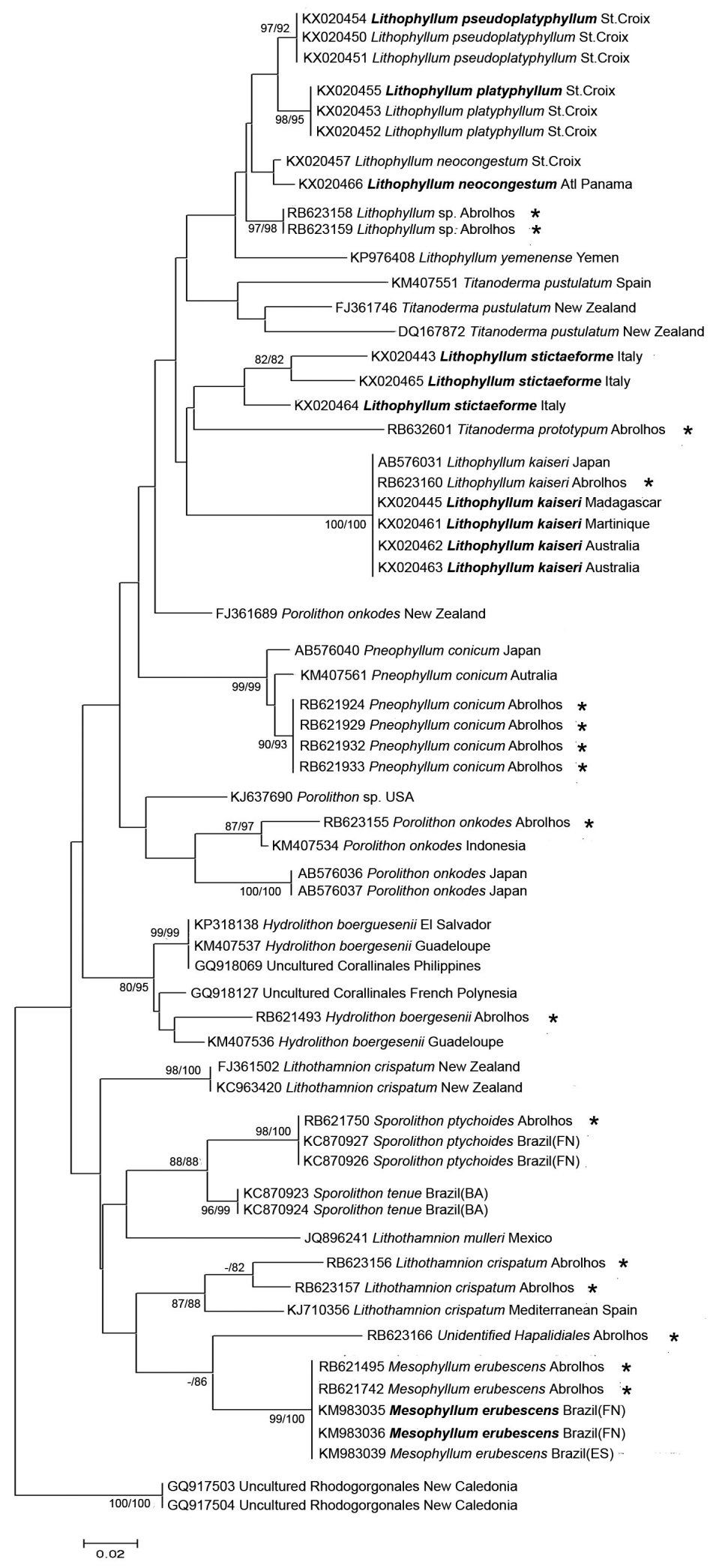

Fig. 11. Phylogram inferred from psbA sequences ( 62 specimens). Species with sequenced type material, complementary rbcL sequences matching type material in other studies (Sissini et al. 2014, Hernandez-Kantun et al. 2016), and sequences from topotypes are represented in bold. Scale represents the number of substitutions per site. Values in the branches nodes represent bootstrap (for 1,000 replicates) for maximum likelihood on the left and neighbor-joining analysis on the right (e.g., 90/98\%). Bootstraps below 80 are not indicated. *Sequences generated in this study. 
Gabrielson et al. (2015) have obtained partial $r b c \mathrm{~L}$ sequences from the type material of S. ptychoides and observed that the type sequences are identical to topotype specimens collected from the Red Sea during their study. From these field-collected topotype specimens, they also obtained $p s b \mathrm{~A}, \mathrm{COI}$, and LSU sequences to compare with published sequences of specimens labeled as S. ptychoides. According to their results, a comparison of the sequence divergence values obtained in their study showed that none of the published sequences from material identified as S. ptychoides from Hawaii, New Caledonia, or Brazil corresponded to the topotype material of S. ptychoides (Gabrielson et al. 2015), indicating that they are likely to have different taxa. However, the sequences mentioned by Gabrielson et al. (2015) are unavailable at GenBank for comparison. Until those sequences can be accessed, we will continue to apply the name of $S$. ptychoides for Brazilian specimens morpho-anatomically identified as such.

\section{CONCLUSION}

In summary, this study provided detailed taxonomic analysis of the NGCA from shallow reefs of the ACS using both morpho-anatomical data and molecular data. Among the nine species identified, only L. kaiseri (new record from Brazil) and M. erubescens had psbA sequences that matched those of type and / or topotype specimens. The phylogenetic analyses presented herein supports the taxon Lithophyllum sp. as a new species to science, confirming the existence of at least two branched Lithophyllum species for the ACS (L. kaiseri and Lithophyllum sp.) rather than only one as previously thought (Figueiredo and Steneck 2000, Tâmega et al. 2014). However, further investigations using more specimens are recommended prior to formal new species description. The taxonomic identifications for the remaining six species were supported by morpho-anatomical evidences. However, their identifications remain doubtful because DNA sequences of their type / topotype are currently unavailable. Sequencing of type material is outside the scope of this study. This study represents the first assessment of phenotypical and genetic diversity of NGCA in the ACS reefs. This study provides useful information for future monitoring and conservation of this important reef system of the South Atlantic.

\section{ACKNOWLEDGEMENTS}

Financial support was obtained from the Brazilian Science Support Agencies CNPq and FAPERJ and funds from P\&D program ANP/BRASOIL. The first author acknowledges the Coordination for the Improvement of Higher Education Personnel (CAPES) for providing a master's scholarship. We also thank CNPq for providing a postdoctoral fellowship grant to RGB (process PDJ 400654/20148) and research fellowship to YYV and GMAF. J.J.H.-K. acknowledges the Smithsonian Institution for providing a postdoctoral fellowship.

\section{SUPPLEMENTARY MATERIAL}

Supplementary Table S1. psbA sequences information (www.e-algae.org).

\section{REFERENCES}

Adey, W. H. \& Adey, P. J. 1973. Studies on the biosystematics and ecology of the epilithic crustose Corallinaceae of the British Isles. Br. Phycol. J. 8:343-407.

Amado-Filho, G. M., Maneveldt, G. W., Pereira-Filho, G. H., Manso, R. C. C., Bahia, R. G., Barros-Barreto, M. B. \& Guimarães, S. M. P. B. 2010. Seaweed diversity associated with a Brazilian tropical rhodolith bed. Cienc. Mar. 36:371-391.

Amado-Filho, G. M., Moura, R. L., Bastos, A. C., Salgado, L. T., Sumida, P. Y., Güth, A. Z., Francini-Filho, R. B., PereiraFilho, G. H., Abrantes, D. P., Brasileiro, P. S., Bahia, R. G., Leal, R. N., Kaufman, L., Kleypas, J. A., Farina, M. \& Thompson, F. L. 2012. Rhodolith beds are major $\mathrm{CaCO}_{3}$ bio-factories in the tropical South West Atlantic. PLoS One 7:e35171.

Antonius, A. 2001. Pneophyllum conicum, a coralline red alga causing coral reef-death in Mauritius. Coral Reefs 19:418.

Athanasiadis, A. \& Ballantine, D. L. 2014. The genera Melyvonnea gen. nov. and Mesophyllum s.s. (Melobesioideae, Corallinales, Rhodophyta) particularly from the central Atlantic Ocean. Nord. J. Bot. 32:385-436.

Bahia, R. G. 2014. Algas coralináceas formadoras de rodolitos da plataforma continental tropical e ilhas oceânicas do Brasil: levantamento florístico e taxonomia. Ph.D. dissertation, Escola Nacional de Botânica Tropical, Rio de Janeiro, $221 \mathrm{pp}$.

Bahia, R. G., Abrantes, D. P., Brasileiro, P. S., Pereira-Filho, G. 
H. \& Amado Filho, G. M. 2010. Rhodolith bed structure along a depth gradient on the northern coast of Bahia State, Brazil. Braz. J. Oceanogr. 58:323-337.

Bahia, R. G., Amado-Filho, G. M., Maneveldt, G. W., Adey, W. H., Johnson, G., Jesionek, M. B. \& Longo, L. L. 2015. Sporolithon yoneshigueae sp. nov. (Sporolithales, Corallinophycidae, Rhodophyta), a new rhodolith-forming coralline alga from the southwest Atlantic. Phytotaxa 224:140-158.

Bahia, R. G., Amado-Filho, G. M., Maneveldt, G. W., Adey, W. H., Johnson, G., Marins, B. V. \& Longo, L. L. 2014. Sporolithon tenue sp. nov. (Sporolithales, Corallinophycidae, Rhodophyta): a new rhodolith-forming species from the tropical southwestern Atlantic. Phycol. Res. 62:44-54.

Bahia, R. G., Riosmena-Rodríguez, R., Maneveldt, G. W. \& Amado Filho, G. M. 2011. First report of Sporolithon ptychoides (Sporolithales, Corallinophycidae, Rhodophyta) for the Atlantic Ocean. Phycol. Res. 59:64-69.

Bailey, J. C. 1999. Phylogenetic positions of Lithophyllum incrustans and Titanoderma pustulatum (Corallinaceae, Rhodophyta) based on 18S rRNA gene sequence analyses, with a revised classification of the Lithophylloideae. Phycologia 38:208-216.

Basso, D., Caragnano, A., Le Gall, L. \& Rodondi, G. 2015. The genus Lithophyllum in the north-western Indian Ocean, with description of L. yemenense sp. nov., L. socotraense sp. nov., L. subplicatum comb. et stat. nov., and the resumed L. affine, L. kaiseri, and L. subreduncum (Rhodophyta, Corallinales). Phytotaxa 208:183-200.

Basso, D., Caragnano, A. \& Rodondi, G. 2014. Trichocytes in Lithophyllum kotschyanum and Lithophyllum spp. (Corallinales, Rhodophyta) from the NW Indian Ocean. J. Phycol. 50:711-717.

Basso, D., Rodondi, G. \& Bressan, G. 2011. A re-description of Lithothamnion crispatum and the status of Lithothamnion superpositum (Rhodophyta, Corallinales). Phycologia 50:144-155.

Bittner, L., Payri, C. E., Maneveldt, G.W., Couloux, A., Cruaud, C., de Reviers, B. \& Le Gall, L. 2011. Evolutionary history of the Corallinales (Corallinophycidae, Rhodophyta) inferred from nuclear, plastidial and mitochondrial genomes. Mol. Phylogenet. Evol. 61:697-713.

Brasileiro, P. S., Pereira-Filho, G. H., Bahia, R. G., Abrantes, D. P., Guimarães, S. M. P. B., Moura, R. L., Francini-Filho, R. B., Bastos, A. C. \& Amado-Filho, G. M. 2016. Macroalgal composition and community structure of the largest rhodolith beds in the world. Mar. Biodivers. 46:407-420.

Broom, J. E. S., Hart, D. R., Farr, T. J., Nelson, W. A., Neill, K. F., Harvey, A. S. \& Woelkerling, W. J. 2008. Utility of $p s b$ A and nSSU for phylogenetic reconstruction in the Coralli- nales based on New Zealand taxa. Mol. Phylogenet. Evol. 46:958-973.

Campbell, S. J. \& Woelkerling, W. J. 1990. Are Titanoderma and Lithophyllum (Corallinaceae, Rhodophyta) distinct genera? Phycologia 29:114-125.

Carro, B., Lopez, L., Peña, V., Bárbara, I. \& Barreiro, R. 2014. DNA barcoding allows the accurate assessment of European maerl diversity: a Proof-of-Concept study. Phytotaxa 190:176-189.

Chamberlain, Y. M., Irvine, L. M. \& Walker, R. 1991. A redescription of Lithophyllum orbiculatum (Rhodophyta, Corallinales) in the British Isles and a reassessment of generic delimitation in the Lithophylloideae. Br. Phycol. J. 26:149-167.

Crespo, T. M., Bahia, R. G., Maneveldt, G. W. \& Amado-Filho, G. M. 2014. Floristic composition of crustose coralline algae from the St. Peter and St. Paul Archipelago, a summit of the Mid-Atlantic Ridge. Phytotaxa 190:17-37.

Da Nóbrega Farias, J., Riosmena-Rodriguez, R., Bouzon, Z., Oliveira, E. C. \& Horta, P. A. 2010. Lithothamnion superpositum (Corallinales; Rhodophyta): first description for the Western Atlantic or rediscovery of a species? Phycol. Res. 58:210-216.

Darriba, D., Taboada, G. L., Doallo, R. \& Posada, D. 2012. jModelTest 2: more models, new heuristics and parallel computing. Nat. Methods 9:772.

Dutra, G. F., Allen, G. R., Werner, T. \& McKenna, S. A. 2005. $A$ rapid marine biodiversity assessment of the Abrolhos Bank, Bahia, Brazil. RAP Bulletin of Biological Assessment 38. Conservation International, Washington, DC, $160 \mathrm{pp}$.

Felsenstein, J. 1985. Confidence limits on phylogenies: an approach using the bootstrap. Evolution 39:783-791.

Figueiredo, M. A. O. \& Steneck, R. S. 2000. Floristic and ecological studies of crustose coralline algae on Brazil's Abrolhos reefs. In Proceedings of the 9th International Coral Reef Symposium, Bali, Vol. 1, pp. 493-497.

Francini-Filho, R. B., Coni, E. O. C., Meirelles, P. M., AmadoFilho, G. M., Thompson, F. L., Pereira-Filho, G. H., Bastos, A. C., Abrantes, D. P., Ferreira, C. M., Gibran, F. Z., Güth, A. Z., Sumida, P. Y. G., Oliveira, N. L., Kaufman, L., Minte-Vera, C. V. \& Moura, R. L. 2013. Dynamics of coral reef benthic assemblages of the Abrolhos Bank, eastern Brazil: inferences on natural and anthropogenic drivers. PLoS One 8:e54260.

Gabrielson, P. W., Hughey, J. R., Richards, J., Sauvage, T., Schmidt, W. \& Fredericq, S. 2015. Sporolithon ptychoides (Sporolithales, Rhodophyta): generitype species of type genus of the order assessed by sequencing type and topotype material. In V International Rhodolith Work- 
shop, Book of Abstracts, Costa Rica, p. 14.

Harrington, L., Fabricius, K., De’ath, G. \& Negri, A. 2004. Recognition and selection of settlement substrata determine post-settlement survival in corals. Ecology 85:3428-3437.

Harvey, A., Woelkerling, W., Farr, T., Neill, K. \& Nelson, W. 2005. Coralline algae of central New Zealand: An identification guide to common 'crustose' species. NIWA Information Series No. 57. National Institute of Water and Atmospheric Research, Wellington, 145 pp.

Harvey, A. S., Woelkerling, W. J. \& Millar, A. J. K. 2009. The genus Lithophyllum (Lithophylloideae, Corallinaceae, Rhodophyta) in south-eastern Australia, with the description of L. riosmenae, sp. nov. Aust. Syst. Bot. 22:296317.

Henriques, M. C., Coutinho, L. M., Riosmena-Rodríguez, R., Barros-Barreto, M. B., Khader, S. \& Figueiredo, M. A. O. 2014. Three deep water species of Sporolithon (Sporolithales, Rhodophyta) from the Brazilian continental shelf, with the description of Sporolithon elevatum sp. nov. Phytotaxa 190:320-330.

Hernandez-Kantun, J. J., Gabrielson, P., Hughey, J. R., Pezzolesi, L., Rindi, F., Robinson, N. M., Peña, V., RiosmenaRodríguez, R., Le Gall, L. \& Adey, W. 2016. Reassessment of branched Lithophyllum spp. (Corallinales, Rhodophyta) in the Caribbean Sea with global implications. Phycologia 55:619-639.

Hernández-Kantún, J. J., Riosmena-Rodríguez, R., HallSpencer, J. M., Peña, V., Maggs, C. A. \& Rindi, F. 2015. Phylogenetic analysis of rhodolith formation in the Corallinales (Rhodophyta). Eur. J. Phycol. 50:46-61.

Kato, A., Baba, M. \& Suda, S. 2011. Revision of the Mastophoroideae (Corallinales, Rhodophyta) and polyphyly in nongeniculate species widely distributed on Pacific coral reefs. J. Phycol. 47:662-672.

Kato, A., Baba, M. \& Suda, S. 2013. Taxonomic circumscription of heterogeneous species Neogoniolithon brassicaflorida (Corallinales, Rhodophyta) in Japan. Phycol. Res. 61:15-26.

Keats, D. W., Chamberlain, Y. M. \& Baba, M. 1997. Pneophyllum conicum (Dawson) comb. nov. (Rhodophyta, Corallinaceae), a widespread Indo-Pacific non-geniculate coralline alga that overgrows and kills live coral. Bot. Mar. 40:263-279.

Le Gall, L., Payri, C. E., Bittner, L. \& Saunders, G. W. 2010. Multigene phylogenetic analyses support recognition of the Sporolithales ord. nov. Mol. Phylogenet. Evol. 54:302-305.

Maneveldt, G. W. 2005. A global revision of the nongeniculate coralline algal genera Porolithon Foslie (defunct) and
Hydrolithon Foslie (Corallinales, Rhodophyta). Ph.D. dissertation, University of the Western Cape, Cape Town, 704 pp.

Maneveldt, G. W. \& Keats, D. W. 2008. Effects of herbivore grazing on the physiognomy of the coralline alga Spongites yendoi and on associated competitive interactions. Afr. J. Mar. Sci. 30:581-593.

Maneveldt, G. W. \& Keats, D. W. 2014. Taxonomic review based on new data of the reef-building alga Porolithon onkodes (Corallinaceae, Corallinales, Rhodophyta) along with other taxa found to be conspecific. Phytotaxa 190:216-249.

Maneveldt, G. W. \& van der Merwe, E. 2012. Heydrichia cerasina sp. nov. (Sporolithales, Corallinophycidae, Rhodophyta) from the southernmost tip of Africa. Phycologia 51:11-21.

Mariath, R., Riosmena-Rodríguez, R. \& Figueiredo, M. 2012. Lithothamnion steneckii sp. nov. and Pneophyllum conicum: new coralline red algae (Corallinales, Rhodophyta) for coral reefs of Brazil. Algae 27:249-258.

Moura, R. L. 2000. Brazilian reefs as priority areas for biodiversity conservation in the Atlantic Ocean. In Proceedings 9th International Coral Reef Symposium, Bali, Vol. 1, pp. 917-920.

Moura, R. L., Secchin, N. A., Amado-Filho, G. M., FranciniFilho, R. B., Freitas, M. O., Minte-Vera, C. V., Teixeira, J. B., Thompson, F. L., Dutra, G. F., Sumida, P.Y. G., Guth, A. Z., Lopes, R. M. \& Bastos, A. C. 2013. Spatial patterns of benthic megahabitats and conservation planning in the Abrolhos Bank. Cont. Shelf Res. 70:109-117.

Nelson, W. A. 2009. Calcified macroalgae: critical to coastal ecosystems and vulnerable to change: a review. Mar. Freshw. Res. 60:787-801.

Nelson, W. A., Sutherland, J. E., Farr, T. J., Hart, D. R., Neill, K. F, Kim, H. J. \& Yoon, H. S. 2015. Multi-gene phylogenetic analyses of New Zealand coralline algae: Corallinapetra Novaezelandiae gen. et sp. nov. and recognition of the Hapalidiales ord. nov. J. Phycol. 51:454-468.

Pereira-Filho, G. H., Amado-Filho, G. M., Guimarães, S. M. P. B., Moura, R. L., Sumida, P. Y. G., Abrantes, D. P., Bahia, R. G., Guth, A. Z., Jorge, R. R. \& Francini Filho, R. B. 2011. Reef fish and benthic assemblages of the Trindade and Martin Vaz island group, southwestern Atlantic. Braz. J. Oceanogr. 59:201-212.

Richards, J. L., Gabrielson, P. W. \& Fredericq, S. 2014. New insights into the genus Lithophyllum (Lithophylloideae, Corallinaceae, Corallinales) from deepwater rhodolith beds offshore the NW Gulf of Mexico. Phytotaxa 190:162-175.

Riosmena-Rodríguez, R., Woelkerling, W. J. \& Foster, M. S. 
1999. Taxonomic reassessment of rhodolith-forming species of Lithophyllum (Corallinales, Rhodophyta) in the Gulf of California, Mexico. Phycologia 38:401-417.

Roberts, R. 2001. A review of settlement cues for larval abalone (Haliotis spp.). J. Shellfish Res. 20:571-586.

Rösler, A., Perfectti, F., Peña, V. \& Braga, J. C. 2016. Phylogenetic relationships of corallinaceae (Corallinales, Rhodophyta): taxonomic implications for reef-building corallines. J. Phycol. 52:412-431.

Saunders, G. W. 2005. Applying DNA barcoding to red macroalgae: a preliminary appraisal holds promise for future applications. Philos. Trans. R. Soc. Lond. B Biol. Sci. 360:1879-1888.

Sissini, M. N., Oliveira, M. C., Gabrielson, P. W., Robinson, N. M., Okolodkov, Y. B., Riosmena-Rodríguez, R. \& Horta, P. A. 2014. Mesophyllum erubescens (Corallinales, Rhodophyta): so many species in one epithet. Phytotaxa 190:299-319.

Tâmega, F. T. S., Riosmena-Rodríguez, R., Mariath, R. \& Figueiredo, M. A. O. 2014. Nongeniculate coralline red algae (Rhodophyta: Corallinales) in coral reefs from Northeastern Brazil and a description of Neogoniolithon atlanticum sp. nov. Phytotaxa 190:277-298.

Tamura, K., Stecher, G., Peterson, D., Filipski, A. \& Kumar, S. 2013. MEGA6: molecular evolutionary genetics analysis version 6.0. Mol. Biol. Evol. 30:2725-2729.

Verheij, E. 1993. The genus Sporolithon (Sporolithaceae fam. nov., Corallinales, Rhodophyta) from the Spermonde Archipelago, Indonesia. Phycologia 32:184-196.

Villas-Boas, A. B., Riosmena-Rodríguez, R., Amado-Filho, G. M., Maneveldt, G. \& Figueiredo, M. A. O. 2009. Rhodolith-forming species of Lithophyllum (Corallinales; Rhodophyta) from Espírito Santo State, Brazil, including the description of $L$. depressum sp. nov. Phycologia 48:237-248.

Walker, R. H., Brodie, J., Russell, S., Irvine, L. M. \& Orfanidis, S. 2009. Biodiversity of coralline algae in the northeastern Atlantic including Corallina caespitosa sp. nov. (Corallinoideae, Rhodophyta). J. Phycol. 45:287-297.

Woelkerling, W. J. \& Campbell, S. J. 1992. An account of southern Australian species of Lithophyllum (Corallinaceae, Rhodophyta). Bull. Br. Mus. Nat. Hist. Bot. 22:1-107.

Woelkerling, W. J., Irvine, L. M. \& Harvey, A. S. 1993. Growthforms in non-geniculate coralline red algae (Corallinales, Rhodophyta). Aust. Syst. Bot. 6:277-293.

Yoon, H. S., Hackett, J. D. \& Bhattacharya, D. 2002. A single origin of the peridinin- and fucoxanthin-containing plastids in dinoflagellates through tertiary endosymbiosis. Proc. Natl. Acad. Sci. U. S. A. 99:11724-11729. 